\title{
B Cells in Rheumatoid Arthritis: Pathogenic Mechanisms and Treatment Prospects
}

\author{
Fengping $\mathrm{Wu}^{1 \dagger}$, Jinfang $\mathrm{Gao}^{2 \dagger}$, Jie $\mathrm{Kang}^{3}$, Xuexue Wang ${ }^{3}$, Qing $\mathrm{Niu}^{1}$, \\ Jiaxi Liu ${ }^{3}$ and Liyun Zhang ${ }^{2 *}$ \\ ${ }^{1}$ School of Basic Medical Sciences, Shanxi Medical University, Taiyuan, China, ${ }^{2}$ Department of Rheumatology, Shanxi \\ Bethune Hospital, Shanxi Academy of Medical Sciences, Tongji Shanxi Hospital, Third Hospital of Shanxi Medical University, \\ Taiyuan, China, ${ }^{3}$ Third Hospital of Shanxi Medical University, Shanxi Bethune Hospital, Shanxi Academy of Medical \\ Sciences, Tongji Shanxi Hospital, Taiyuan, China
}

OPEN ACCESS

Edited by: Attila Mócsai,

Semme/weis University, Hungary

Reviewed by:

Changrong Ge,

Karolinska Institutet (KI), Sweden Nathalie Balandraud, Assistance publique des hôpitaux de Marseille AP-HM, France

${ }^{*}$ Correspondence: Liyun Zhang 1315710223@qq.com

${ }^{\dagger}$ These authors have contributed equally to this work and share first authorship

Specialty section: This article was submitted to Autoimmune and Autoinflammatory Disorders, a section of the journal

Frontiers in Immunology

Received: 31 July 2021 Accepted: 10 September 2021 Published: 28 September 2021

Citation: Wu F, Gao J, Kang J, Wang X, Niu Q, Liu J and Zhang L (2021) $B$ Cells in Rheumatoid Arthritis:

Pathogenic Mechanisms and Treatment Prospects.

Front. Immunol. 12:750753. doi: 10.3389/fimmu.2021.750753
Rheumatoid arthritis (RA) is a common, chronic, systemic autoimmune disease, and its clinical features are the proliferation of joint synovial tissue, the formation of pannus and the destruction of cartilage. The global incidence of $\mathrm{RA}$ is about $1 \%$, and it is more common in women. The basic feature of RA is the body's immune system disorders, in which autoreactive $\mathrm{CD} 4^{+} \mathrm{T}$ cells, pathogenic $\mathrm{B}$ cells, M1 macrophages, inflammatory cytokines, chemokines and autoantibodies abnormally increase in the body of RA patients B cell depletion therapy has well proved the important role of B cells in the pathogenesis of RA, and the treatment of RA with $B$ cells as a target has also been paid more and more attention. Although the inflammatory indicators in RA patients receiving B-cell depletion therapy have been significantly improved, the risk of infection and cancer has also increased, which suggests that we need to deplete pathogenic B cells instead of all B cells. However, at present we cannot distinguish between pathogenic B cells and protective $B$ cells in RA patients. In this review, we explore fresh perspectives upon the roles of $B$ cells in the occurrence, development and treatment of RA.

Keywords: B cells, rheumatoid arthritis, ACPA, RF, autoreactive, therapeutic approaches

\section{B CELLS IN THE SYNOVIUM OF RA PATIENTS}

The synovial tissue of RA patients can be regarded as tertiary lymphoid tissues (TLTs) or ectopic lymphoid structures. Its structure is similar to secondary lymphoid tissue, with $\mathrm{T}$ cell and B cell differentiation sites. TLTs are correlated with autoantibody titers, inflammatory cytokine levels, and disease severity in RA patients, indicating that TLTs are related to the continuous inflammation in RA (1). In addition, accumulation of B cells in TLTs is related to the increase of radiographic scores and $\mathrm{T}$ cell activation in RA patients (2). There are abundant chemokines and inflammatory factors (LT $\alpha$, LT $\beta$, CXCL13, CCL20, CCL21, and CXCL12) in TLTs. These cytokines promote the infiltration of inflammatory cells into joints and the production of TLTs, which aggravates the formation of pannus and synovial hyperplasia (3). LT $\alpha$ and LT $\beta$ secreted by B cells are very important for maintaining the aggregated T cell and B cell infiltrate in TLTs (4). There are also 
plasmablasts that produce autoantibodies in TLTs, and even long-lived plasma cells (usually only in the bone marrow and are the main source of ACPA) (5). Interestingly, RA patients treated with etanercept (combined with TNF and LT $\alpha$ ) had significantly fewer new TLTs in the synovium, which further illustrates the importance of B cells for TLTs production (6). TLTs have part of the functions of secondary lymphoid tissues, support B cell antigen presentation and interaction with $\mathrm{T}$ cells, and are conducive to the further differentiation and maturation of B cells. Studies have shown that $B$ cells accumulated in the synovial membrane of RA have undergone somatic hypermutation (7). Activation-induced cytidine deaminase (AID) plays a major role in B cell somatic hypermutation and class switching recombination in TLTs (7). In addition to plasma cells, TLTs also have a large number of anticitrullinated protein antibodies (ACPA) and rheumatoid factor (RF), so TLTs contribute to the production of autoantibodies in the synovium $(8,9)$ (Figure 1).

The results of single-cell sequencing showed that the ratio of double negative $\left(\mathrm{CD} 27^{-} \mathrm{IgD}^{-}\right)$and class-switched memory $\left(\mathrm{CD} 27^{+} \operatorname{IgD}^{-}\right) \mathrm{B}$ cells in the synovium of RA patients was significantly higher than that of peripheral blood, which shows these two types of B cell subgroups may play a key role in the pathogenesis of RA (10). Compared with other B cell subgroups, class-switched memory $\mathrm{B}$ cells $\left(\mathrm{CD} 27^{+} \mathrm{IgD}^{-}\right)$are particularly prone to express RANKL after activation (11). Double-negative B cells often highly express miR-155, which is essential for B cells to produce autoantibodies $(12,13)$. In addition, there is a type of CD $21^{-/ \text {low }} \mathrm{B}$ cells in the synovial fluid of RA patients with serum ACPA positive. CXCR3 is expressed on the surface of these cells, and RANKL can be secreted under the stimulation of IL- 6 to induce osteoclast differentiation and ultimately cause bone destruction in RA patients (14). Obviously, CD $21^{-/ \text {low }} \mathrm{B}$ cells belongs to pathogenic $\mathrm{B}$ cells and can be used as a potential target for the treatment of RA in the future.

\section{B CELL CHECKPOINTS IN RA}

B cell checkpoints refer to a series of sites that affect the proliferation, differentiation, apoptosis and other physiological processes of all B cells during their development. These sites include receptors on the surface of $\mathrm{B}$ cells and their ligands (Figure 2).

\section{BCR, TLR, and CD40}

Two signals are usually needed to activate B cells: BCR signal and costimulatory signal. The combination of antigen and BCR provides the first signal for $B$ cell activation, and the

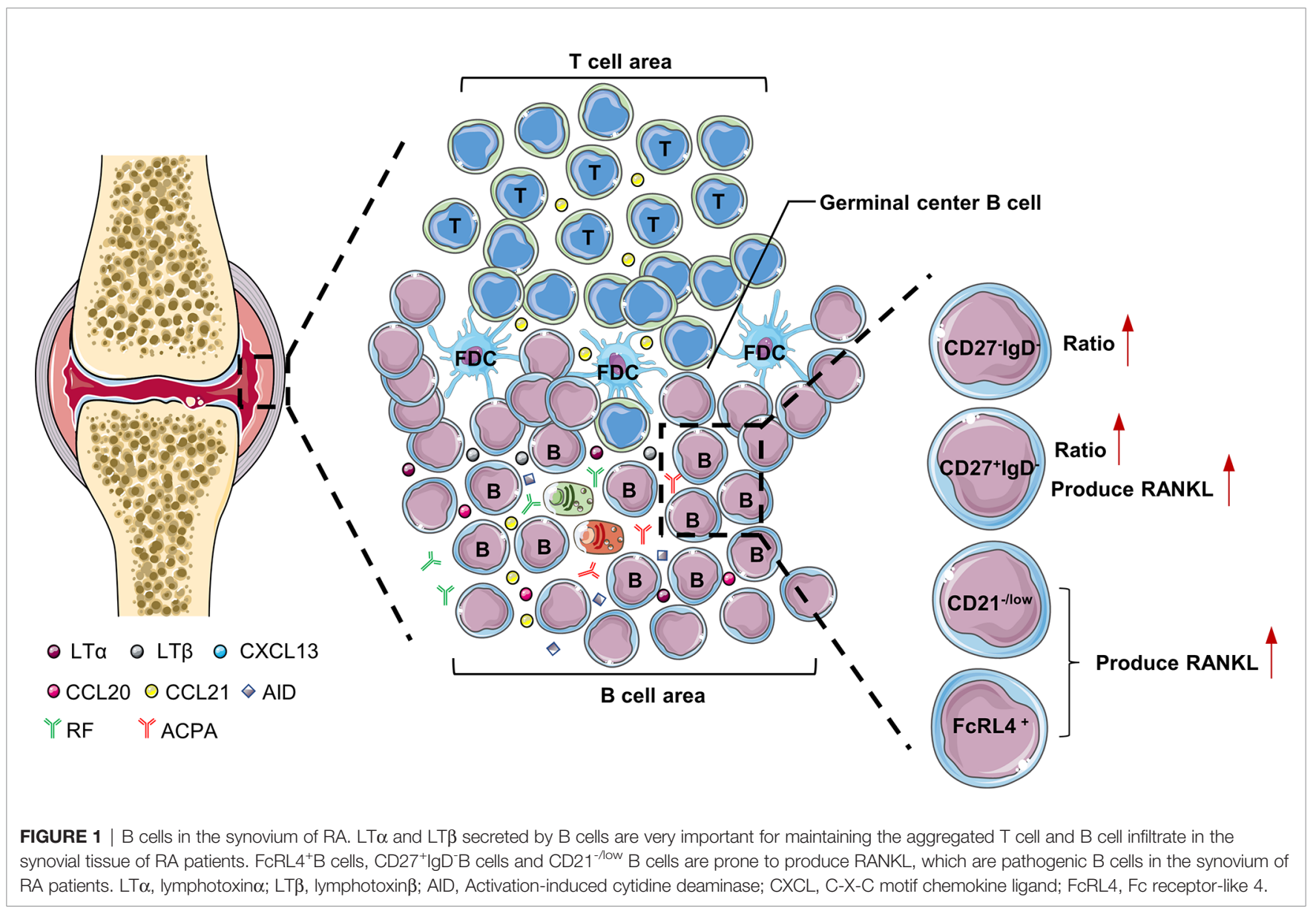


A

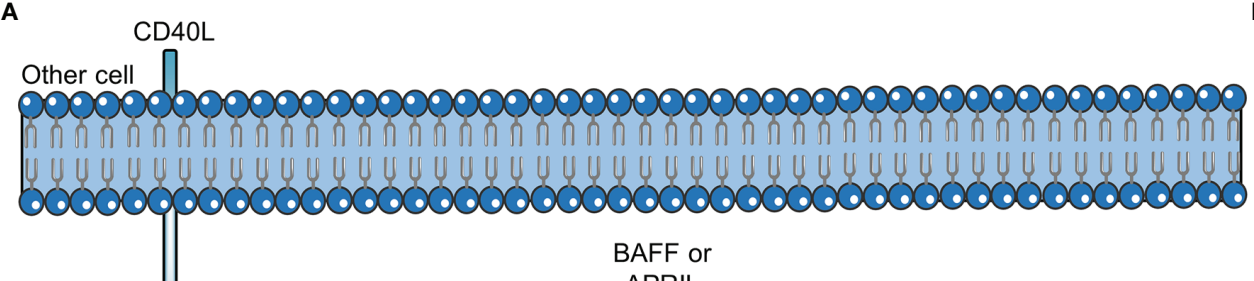

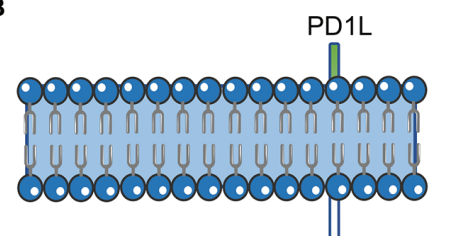
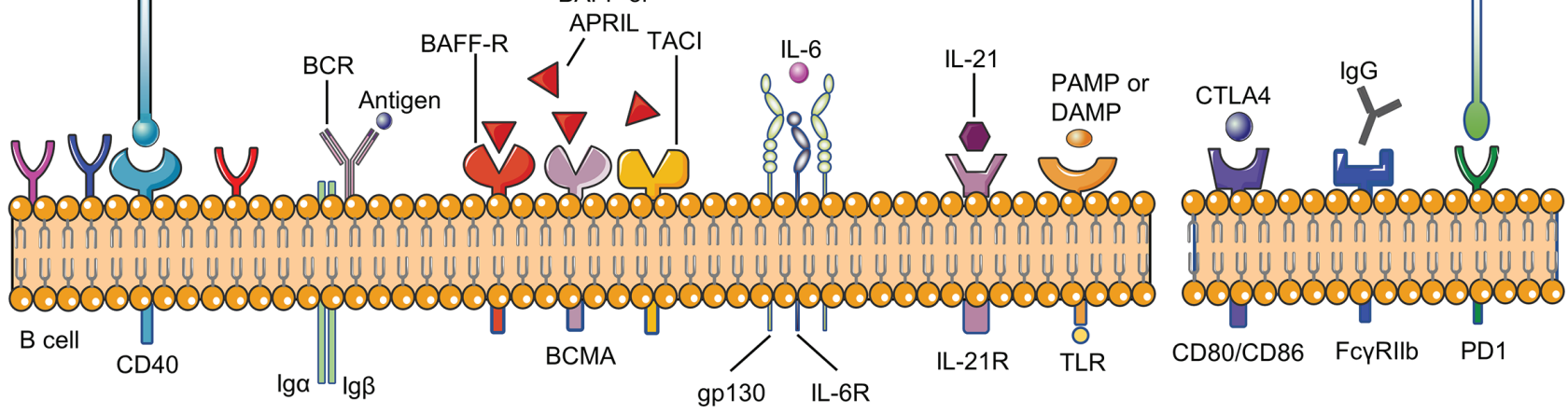

FIGURE 2 | B cell checkpoints in RA. B cell checkpoints provide signals for the survival, development, differentiation, inhibition and other physiological processes of all B cells. (A) stimulatory checkpoint. (B) inhibitory checkpoint. BCR,B cell receptor; CD40L, CD40 ligand; BAFF, B cell activating factor; BAFFR, B cell activating factor receptor; DAMP, damage- associated molecular pattern; PAMP, pathogen- associated molecular pattern; Fc $\gamma R \| \beta$, FC gamma receptor $\| \beta$; IL-21R, IL-21 receptor; IL-6R, IL-6 receptor; PD1, programmed cell death 1; CTLA4, cytotoxic T lymphocyte-associated antigen-4.

costimulatory signal is important for $\mathrm{B}$ cells to overcome inhibitory checkpoints. TLR and CD40 on B cells are mainly responsible for providing costimulatory signals. In RA, BCR signaling has been proved to be involved in the development of autoreactive B cells (15). CD40L (CD40 ligand) on the activated $\mathrm{T}$ cell membrane will promote the formation of memory $\mathrm{B}$ cells and long-lived plasma cells. Without the co-stimulation of CD40 or other receptors, only activating the BCR signal will lead to B cell apoptosis. CD40L is significantly up-regulated in T cells in RA, and the level of soluble CD40L is correlated with autoantibody titers and disease activity in RA patients $(16,17)$. Clinical trials have shown that VIB4920 (a CD40L inhibitor) can inhibit the activation and differentiation of $B$ cells and reduce the disease activity of RA patients (18). In addition, B cells can be activated in a $\mathrm{T}$ cell-independent manner by dual stimulation of BCR and TLR. TLR recognizes pathogen-associated molecular patterns (PAMP) and damage-associated molecular patterns (DAMP). TLR-7 and TLR-9 are necessary for the production of anti-RNA and dsDNA autoantibodies, respectively $(19,20)$. Studies have confirmed that the expression of TLR10 on B cell subsets in RA patients is related to disease activity, but the effect of TLR-10 on B cells needs further research (21).

\section{BAFF and APRIL}

B-cell activating factor (BAFF) and A proliferation-inducing ligand (APRIL) are two members of the TNF superfamily. They have similar structures and are necessary for the growth and development of B cells $(22,23)$. BAFF and APRIL correspond to three types of receptors: $\mathrm{B}$ cell maturation antigen (BCMA), transmembrane activator and CAML interactor (TACI), BAFF-receptor (BAFF-R). BAFF-R is expressed on almost all B cells, and its importance for the survival of $B$ cells is far greater than the other two receptors. Excessive BAFF in peripheral blood promotes the survival of autoreactive B cells and the production of autoantibodies (24). Studies have shown that compared with healthy individuals, the levels of BAFF and APRIL in the peripheral blood of RA patients are significantly higher; the levels of BAFF and APRIL in the synovial fluid of RA patients are also higher than those in the serum (25). BAFF and APRIL are constitutively expressed by various types of cells (including neutrophils, follicular dendritic cells, macrophages, and fibroblast-like synoviocytes) in RA patients, and their expression will be significantly increased in the inflammatory environment (25). The serum BAFF level of RA patients is positively correlated with the RF titer of seropositive RA patients, indicating that BAFF plays a key role in the occurrence or continuation of the disease (26). In the presence of BAFF, TLR ligands will promote B cell activation, class switching, somatic hypermutation and differentiation into plasma cells, leading to the production of harmful autoantibodies $(27,28)$. As a homologous of BAFF, APRIL can cause the accumulation of plasma cells in the joints and further increase the production of inflammatory cytokines such as TNF- $\alpha$, IL-1 and IL-6 (29). Zhang LL et al. found that BAFF can promote B cell activation and differentiation through the NF- $\kappa \mathrm{B}$ pathway, leading to the production of autoantibodies and inflammatory cytokines, and ultimately causing bone erosion and destruction in RA patients (26). In addition, inhibiting the expression of BAFF receptors will significantly reduce the proportion and number of $B$ cells and the level of anti-collagen IgG in collagen-induced arthritis (CIA) mice, ultimately leading to a reduction in joint inflammation (30). 


\section{IL-6}

IL-6 was initially identified as a B cell growth factor and plasma cell differentiation factor, and was mainly produced by B cells and macrophages in the synovial fluid of RA patients $(31,32)$. Compared with healthy individuals, the concentration of IL-6 in serum and synovial tissue of RA patients is increased. In RA, increased serum concentration of IL- 6 is associated with joint damage, which may be because IL- 6 is involved in the promotion of osteoclast formation (33). Blocking IL-6 with tocilizumab (anti-IL-6 receptor (IL-6R) monoclonal antibody) can inhibit IgD ${ }^{-} \mathrm{CD} 27^{-}$memory B cells and significantly improve the clinical symptoms of RA patients $(34,35)$.

\section{IL-21}

The cytokine IL-21 is produced by multiple helper T cell subsets, and has key functions in B cell activation, proliferation, differentiation, affinity maturation and antibody production. IL21 drives the pro-inflammatory response by promoting B cell activation and expansion. Compared with healthy individuals, the concentration of IL-21 in the synovium and serum of RA patients is significantly increased (36). In addition, the proportion of IL-21R ${ }^{+}$ $\mathrm{B}$ cells in RA patients is also significantly higher than that in healthy people (37). In germinal center, IL-21 secreted by T follicular helper cells (Tfh) activates AID to regulate class switching of B cells and promote their differentiation into memory B cells and plasma cells (38). Therefore, blocking IL-21 will lead to the reduction of T cellinduced $\mathrm{B}$ cell proliferation and differentiation, and reduce the inflammatory response. In addition, IL-21R knockout mice are resistant to induction of CIA, indicating that IL-21 signaling in B cells is essential for the development of CIA (39). Treatment of CIA mice with IL-21R.Fc fusion protein can reduce their clinical signs, antibody levels and IL-6 levels, which also proves the important role of IL-21 in the development of CIA (40). New research shows that IL-21 can increase the binding of specificity protein 1 and IL21R promoter in $\mathrm{B}$ cells, leading to enhanced $\mathrm{B}$ cell response in RA patients (41). Since IL-21 promotes the function of B cells in RA patients through multiple mechanisms, targeting IL-21 as a treatment for RA may be valuable in the future.

\section{FcyRIIb}

Fc gamma receptor II $\beta$ (Fc $\gamma \mathrm{RII} \beta)$ is an inhibitory receptor that can inhibit BCR-mediated signal transduction and avoid excessive B cell activation (42). When BCR signal is activated by antigen, Fc $\gamma$ RII $\beta$ bound to BCR can further activate tyrosine kinase (Lyn) and immunoreceptor tyrosine based inhibitory motif (ITIM), and then recruit tyrosine phosphatase-1 (SHP-1) to inhibit signal downstream of BCR (43). Related studies have shown that Fc $\gamma$ RII $\beta$ helps prevent autoimmunity, and mutations in its genetic locus are related to RA (44). Hu C et al. found that YSTB (Yishentongbi decoction) can inhibit the excessive activation of $\mathrm{B}$ cells by activating the FcyRIIb/Lyn/SHP-1 pathway, thereby reducing the joint inflammation in CIA rats (45).

\section{Other Checkpoints}

Other checkpoints, such as CD19, cytotoxic T lymphocyteassociated antigen-4 (CTLA4), programmed cell death 1
(PD1), also play important roles in the pathogenesis of B cells in RA $(2,46)$. As our understanding of their pathogenic mechanism gradually improves, these receptors can provide new targets for the future treatment of RA.

\section{B CELL TOLERANCE CHECKPOINTS}

$B$ cell tolerance checkpoints are mainly used to study self-reactive $\mathrm{B}$ cells, which refer to sites that regulate $\mathrm{B}$ cell tolerance and control the number of self-reactive $B$ cells in the body during the development of B cells. These sites are distributed in the bone marrow, peripheral blood and germinal centers, but they have not been studied clearly. First of all, when the pre-B cells of the bone marrow develops to the immature B cells, they will be checked by the first tolerance checkpoint. Through clonal deletion, receptor-editing, anergy and other mechanisms, most of the autoreactive $\mathrm{B}$ cells in the bone marrow are eliminated (47). After immature B cells leave the bone marrow, they undergo a second tolerance checkpoint when they differentiate from new emigrant/transitional B cells into mature naive B cells in the blood and spleen Inspection. Through regulatory $\mathrm{T}$ cells to provide inhibitory signals and other mechanisms, the number of self-reactive B cells is further reduced (48). The mature naive B cells are activated after being stimulated by antigens, and the activated autoreactive B cells are corrected through costimulatory signals provided by $\mathrm{T}$ helper cells ( $\mathrm{T}$ helper cells) and follicular dendritic cells (FDC) or somatic hypermutation (SHM) in the germinal center, thereby further reducing the production of autoreactive memory B cells and plasma cells $(49,50)$. However, some autoreactive B cells in RA patients have not been corrected after SHM. After they differentiate into plasma cells, they will secrete high-affinity ACPA and other autoantibodies, so they are more pathogenic $(50,51)$. The study found that compared with healthy individuals, the proportion of autoreactive new emigrant/transitional $\mathrm{B}$ cells and mature naive $\mathrm{B}$ cells in the peripheral blood of RA patients was significantly increased, indicating the central and peripheral B cell tolerance checkpoints of RA patients have been impaired (Figure 3).

Current research shows that ACPA-specific B cells and RFspecific $B$ cells are the two main types of autoreactive $B$ cells in RA (52). Mahendra et al. successfully isolated CCP ${ }^{\text {pos }}$ and $\mathrm{CCP}^{\text {neg }} \mathrm{B}$ cells in the peripheral blood of RA patients and performed transcriptome sequencing (53). They found that compared with $\mathrm{CCP}^{\text {neg }} \mathrm{B}$ cells, $\mathrm{CCP}^{\mathrm{pos}} \mathrm{B}$ cells highly expressed IL-15R $\alpha$, which may be a future therapeutic target for autoreactive B in RA patients (53). Germar et al. found that compared with $\mathrm{CCP} 2^{\text {neg }} \mathrm{B}$ cells, $\mathrm{CCP} 2^{\text {pos }} \mathrm{B}$ cells express high levels of CD40 and C5aR1 on the surface (54). C5aR1 may also be the surface markers of ACPA-specific B cells, but the sample size needs to be expanded for further confirmation. Tetramer technology is currently a good method for isolating autoreactive $B$ cells in RA patients, which is beneficial to further research on $B$ cell tolerance in RA patients in the future. The current research progress is limited to several mechanisms of how B cells escape the peripheral B cells tolerance checkpoint. The future research 


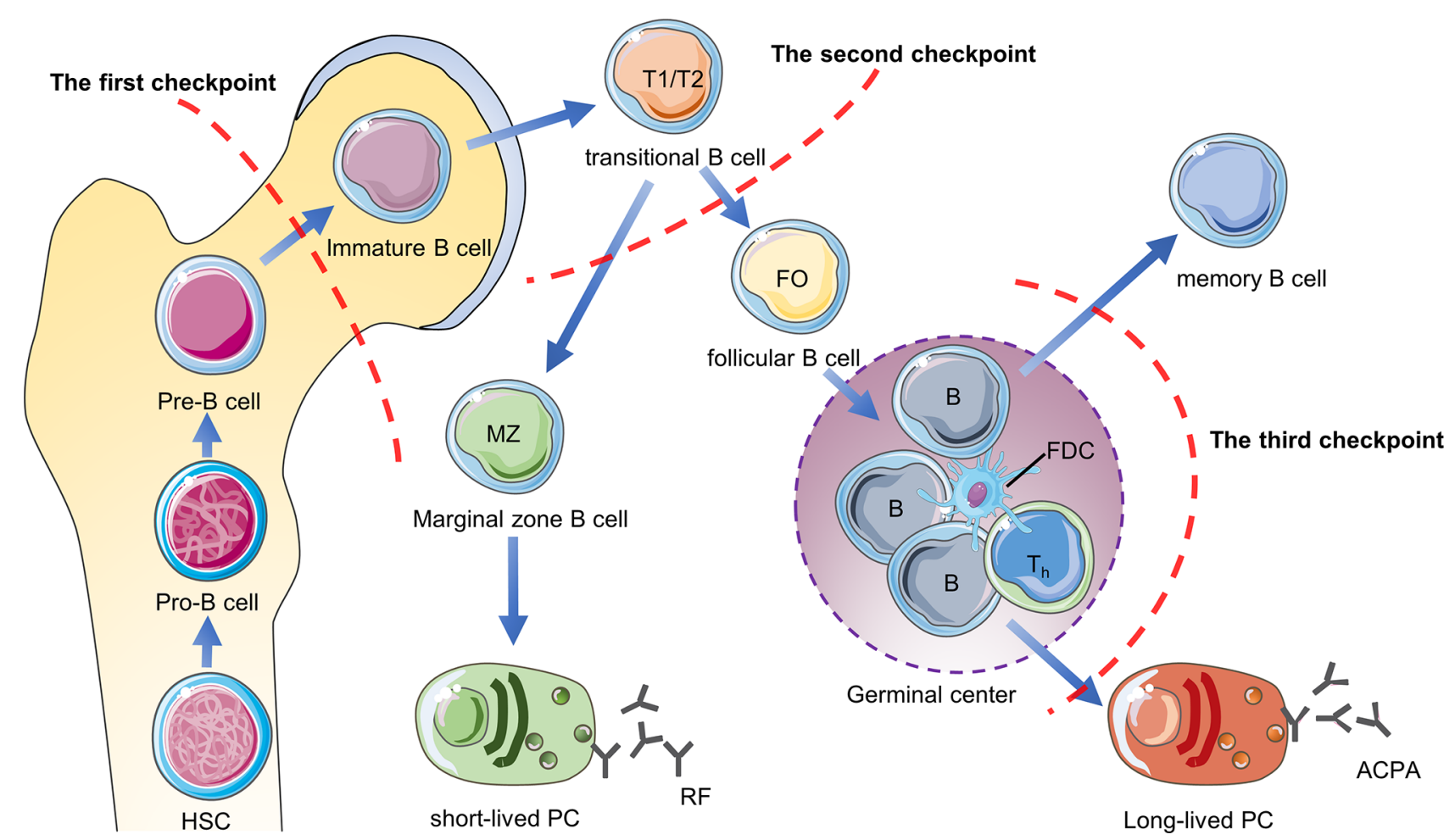

FIGURE 3 | B cell tolerance checkpoints in RA. B cell tolerance checkpoints are "checkpoints" to reduce the number of autoreactive B cells in RA patients. After these checkpoints are impaired, a large number of autoreactive B cells will accumulate in RA patients and cause the production of autoantibodies such as RF and ACPA. HSC, hematopoietic stem cells; PC, plasma cells.

direction is to further clarify the mechanism of B cell tolerance checkpoint damage and to find biomarkers that distinguish between autoreactive B cells and non-autoreactive B cells, which will provide the basis for precise depletion of selfreactive $B$ cells to treat $R A$.

\section{B CELLS IN THE PATHOGENESIS OF RA}

The functions of B cells, including antigen presentation, cytokine secretion and autoantibody production, are all related to the pathogenesis of RA (Figure 4).

\section{Antigen Presentation}

There are three main types of antigen-presenting cells in the human body: dendritic cells (DC), macrophages, and B cells. APC can rapidly endocytose, process and present antigens to $\mathrm{CD} 4{ }^{+}$helper $\mathrm{T}$ cells to cause related immune responses. B cells are essential APCs in proteoglycan-induced arthritis (PGIA). In the early stage of CIA, autoreactive $\mathrm{B}$ cells may trigger or exacerbate the disease by activating autoreactive $\mathrm{T}$ cells. As the number of autoreactive B cells increases during inflammation, these B cells may play an increasingly important role in the activation of autoreactive T cells. In the PGIA model, PG-specific $\mathrm{B}$ cells are necessary to activate autoreactive $\mathrm{T}$ cells. In the absence of PG-specific B cells, the PG-specific T cells in the modeled mice cannot be activated, and eventually arthritis will not develop (55). Besides, citrullinated proteins are also major autoantigens that affects RA disease progression. Previous studies indicated that HLA-DRB1 alleles may bind citrullinated peptides and present them to $\mathrm{T}$ helper cells specific for citrullinated proteins (56). However, further researches show increased citrullination of self-antigens do not improve binding affinity for HLA-DR alleles and there is no evidence shows that citrullinated peptides preferentially bind to HLA-DR alleles (57, 58). Auger et al. found HLA-DR alleles could bind to PAD4 (an enzyme that binds and citrullinates multiple proteins) and use it as a carrier to internalize and process the PAD4-citrullinated protein complex, and present the PAD4 peptides to $\mathrm{T}$ helper cells, which could eventually lead to the production of IgG antibodies to multiple citrullinated proteins (59).

In RA, B cells, as APCs, mainly present their own antigens to $\mathrm{CD} 4^{+} \mathrm{T}$ helper cells. $\mathrm{CD} 4^{+}$helper $\mathrm{T}$ cells are divided into follicular helper cells (Tfh) and peripheral helper cells (Tph). Compared with healthy individuals, Tfh cells and Tph cells in the synovium and peripheral blood of RA patients are significantly increased. Tfh cells and Tph cells can secrete CXCL13 and IL-21, and the latter is very important for the differentiation of $B$ cells and the production of autoantibodies (60-62). After B cells present antigens to Tfh cells, Tfh cells can promote the affinity 


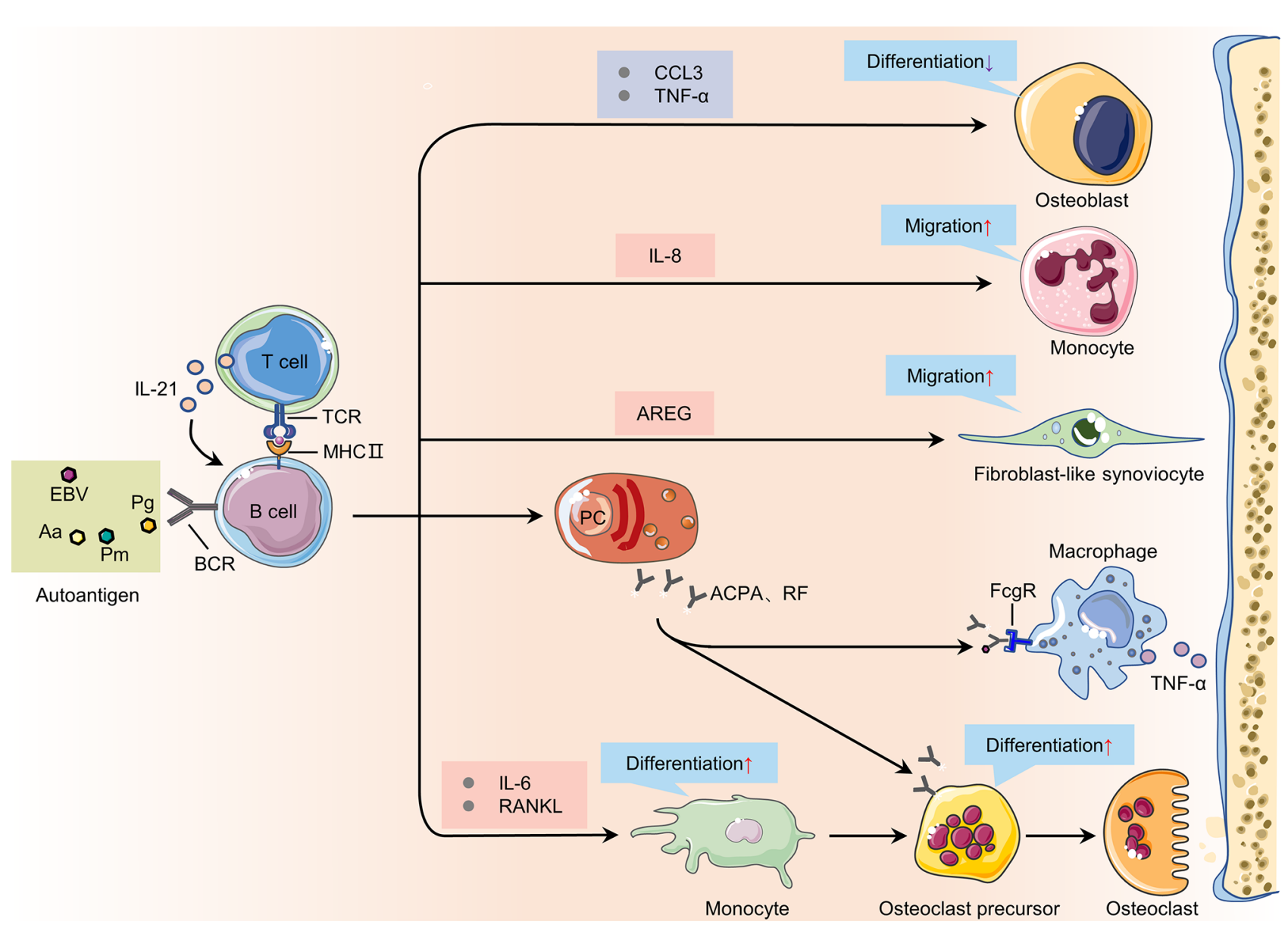

FIGURE 4 | The immunopathogenic role of B cells in rheumatoid arthritis. During the onset of RA, B cells can promote the activation, proliferation, and differentiation of other cells such as T cells, monocytes, and osteoclasts in the synovium by providing cytokines, autoantibodies and other mediators. TCR, T cell receptor; MHC II, major histocompatibility complex class II; TNF- $\alpha$, tumor necrosis factor- $\alpha$; FcgR, Fcgamma receptors; AREG, amphiregulin; RANKL, receptor activator of nuclear factor kappa-B ligand; Pg, Porphyromonas gingivalis; Aa, Aggregatibacter actinomycetemcomitans; Pm, Proteus mirabilis; EBV, Epstein-Barr virus; PC, plasma cells.

maturation of B cells. Several studies have observed that the proportion of $\mathrm{CD} 4^{+} \mathrm{Tfh}$ cells is positively correlated with serum ACPA titer in RA patients (63-65).

\section{Cytokine Secretion}

In the synovium of RA patients, there is a complex network of cytokines, which are closely related to the occurrence of the disease. B cells in the peripheral blood of RA patients can secrete a variety of different cytokines to participate in bone destruction, including: TNF- $\alpha$, IFN- $\gamma$, IL-6, IL-1 $\beta$, IL-17 and IL-10 (66). Compared with ACPA negative RA patients, ACPA positive RA patients have significantly higher levels of IL-1 $\beta$, CCL20, IL-17F and IL-10 in synovial fluid (67). After TLR9 and CD40 are activated, the amount of TNF- $\alpha$ produced by the B cells of RA patients is higher than that of healthy individuals (68). TNF- $\alpha$ can increase the expression of RANKL by B cells in the presence of IL-1 $\beta$, thereby promoting the formation of osteoclasts (69). Sun $\mathrm{W}$ et al. found that B cells can also inhibit the differentiation of osteoblasts by producing TNF- $\alpha$ and CCL3 to inhibit bone formation in RA patients (70). IL-6 derived from B cells can promote its own proliferation and exert pleiotropic effects on $\mathrm{T}$ cells and other cells (71). RANKL is mainly secreted by memory B cells expressing Fc receptor like 4 (FcRL4) in the joints of RA patients, but these cells have low plasma cell differentiation potential $(72,73)$. In vitro experiments have shown that RANKL secreted by B cells can promote the differentiation of monocytes into osteoclasts, leading to bone damage in RA (11). IFN- $\gamma$ secreted by B cells can maintain PGIA by promoting the production of autoreactive T cells and Tfh $(74,75)$. Kristyanto $\mathrm{H}$ et al. found that ACPA-positive B cells in the blood and synovial fluid of RA patients could secrete the chemokine interleukin 8 to attract neutrophils to the site of inflammation (76).

Regulatory B (Breg) cells are a type of B cells that exert immunosuppressive functions. In contrast to pro-inflammatory B cell responses, Breg cells are mainly responsible for the production of anti-inflammatory cytokines such as IL-10, TGF $\beta$ and IL-35. Breg cells can inhibit disease progression in RA, and the decrease in their number is related to the increase in disease 
activity of RA patients $(77,78)$. Human Breg cells are mainly enriched in transitional $\left(\mathrm{CD} 19^{+} \mathrm{CD} 24^{\mathrm{hi}} \mathrm{CD} 38^{\mathrm{hi}}\right)$ and memory $\left(\mathrm{CD} 19^{+} \mathrm{CD} 24^{\text {hi }} \mathrm{CD} 27^{+}\right) \mathrm{B}$ cells $(79)$. CD $19^{+} \mathrm{CD} 24^{\text {hi }} \mathrm{CD} 38^{\text {hi }} \mathrm{B}$ cells can inhibit the production of inflammatory factors such as IFN- $\gamma$ and IL- 21 by $\mathrm{T}$ cells in RA patients, while reducing the production of ACPA $(80,81)$. In addition, $\mathrm{CD} 19^{+} \mathrm{CD} 24^{\mathrm{hi}} \mathrm{CD} 27^{+} \mathrm{B}$ cells derived from peripheral blood also play an important role in immune regulation and participate in inflammatory response (82). TGF $\beta$ is produced by some other Breg cells and also regulate T cell activity (83). In 2014, Shen P et al. described a group of Breg cells that suppress autoimmunity and secrete IL-35 $(84,85)$. There are two main regulatory $\mathrm{B}$ cell populations in mice: transitional $\mathrm{B}$ cells $\left(\mathrm{CD} 19^{+} \mathrm{CD} 21^{\mathrm{hi}} \mathrm{CD} 23^{\mathrm{hi}} \mathrm{CD} 1 \mathrm{~d}^{\mathrm{hi}}\right)$ have been shown to prevent arthritis (86), and B10 B cells $\left(\mathrm{CD} 19^{+} \mathrm{CD}^{+} \mathrm{CD} 1 \mathrm{~d}^{\text {hi }}\right)$ has been shown to maintain immune tolerance by inhibiting Th1/Th17 response and promoting Treg cell production in murine arthritis (87). Breg cells play an important role in alleviating the inflammatory response in RA patients, and how to restore or enhance the immunosuppressive function of Breg cells in RA patients still needs further research.

\section{Autoantibody Production}

Autoantibodies are mainly secreted and produced by autoreactive $\mathrm{B}$ cells after they differentiate into plasma cells. The cross-reactivity of some post translational modification proteins and foreign antigens may drive the expansion of autoreactive B cells in RA (88). Current studies have confirmed that microorganisms from the intestines and lungs may induce the onset of RA. These microorganisms include Porphyromonas gingivalis $(\mathrm{Pg})(89,90)$, Aggregatibacter actinomycetemcomitans (Aa) (91), Proteus mirabilis (Pm) (92) and Epstein-Barr virus (EBV) (93). The autoantibodies of RA mainly include RF, ACPA, anti-modified citrullinated vimentin antibody, anticarbamylated protein antibody, anti-PAD-4 antibody, anti-GPI antibody and so on (94). Many years before the onset of RA, autoantibodies such as RF and ACPA appeared in the patient's serum (95). However, ACPA-specific B cells and RF-specific B cells have different developmental trajectories: ACPA-specific B cells undergo more rounds of germinal center reactions than RFspecific B cells (96). Compared with RF-specific B cells, ACPAspecific $B$ cells have a higher proportion of somatic hypermutation and class switching (96). ACPA is present in approximately $70 \%$ of RA patients $(97,98)$, and compared with seronegative RA patients, patients positive for RF or ACPA have more severe disease progression $(99,100)$. ACPA is not limited to recognize citrullinated protein, but can also cross-react with acetylated and carbamylated proteins $(88,101,102)$.

Autoantibodies such as RF and ACPA participate in the pathogenesis of RA through multiple mechanisms. In RA, immune complexes containing RF or ACPA activate the complement pathway, leading to the production of $\mathrm{C} 5 \mathrm{a}$ and membrane attack complex, both of which can cause damage to the joints (103). The immune complex formed by RF and autoantigens can also induce osteoclast differentiation through $\mathrm{F} c \gamma$ receptors $(\mathrm{Fc} \gamma \mathrm{R})$ to mediate bone destruction in RA patients (104). ACPAs are serum markers for the diagnosis of RA, and
Approximately $90 \%$ of ACPA-IgG molecules carry N-glycans on the Fab-domain (105). In contrast to Fc glycans, these $\mathrm{N}$-glycans on the Fab-domain are highly sialylated (106). N-glycans on the Fab-domain of ACPA-IgG can reduce the affinity to non-self antigens to provide survival advantages for autoreactive B cells (107). Sehnert et al. found that increasing the sialylation of IgG antibodies can reduced the number of $\mathrm{CD} 138^{+} / \mathrm{TACI}^{+}$plasma cells and $\mathrm{CD} 9^{+} \mathrm{B}$ cells in CIA mice to relieve their joint inflammation (108). In addition, the ACPA response in RA patients was characterized by extensive somatic hypermutation and limited avidity maturation (109, 110). Despite these advances, we are still uncertain how these characteristics are related to the process that eventually leads to arthritis. Mahendra et al. found that the combination of amphiregulin (AREG) produced by B cells and ACPA will further lead to osteoclast differentiation, which is the first comprehensive study on the transcriptome profile of ACPA-specific B cells and will serve as a resource to further investigate the role of autoreactive $B$ cells in RA (53). Understanding the role of ACPA Fab-domain glycans in the development of ACPA-expressing B cells, together with the transcriptional profile of ACPA-specific B cells, will help us develop new therapies targeting autoreactive $B$ cells in RA.

\section{B CELLS IN THE PREVENTION OF RA}

In addition, we must be aware that not all $\mathrm{B}$ cells can promote the pathogenesis of RA, and that some antibodies produced by $\mathrm{B}$ cells have a preventive and protective effect on RA, such as naturally arising antibodies (NAbs) $(111,112)$, therapeutic anticitrullinated protein antibodies (tACPAs) (113). In patients with autoimmune disease, higher levels of NAbs correlate with fewer cardiovascular events (114). A study in 2012 pointed out that compared with RA patients with high levels of IgM antiphosphorylcholine NAbs, patients with low levels of NAbs had higher frequency of cardiovascular events within 5 years (112). In the experimental models, IgM NAbs can significantly reduce the clinical scores of their damaged joints and even prevent the development of inflammatory arthritis (114). The above studies fully demonstrate that antibodies produced by some B cells have a protective effect on RA. The capacity for NAbs influence pathogenesis of RA in people has not yet been directly examined and it remains to be further studied. tACPAs are also protective antibodies that specifically bind to citrulline at position 3 (Cit3) in histone 2A (citH2A) and 4 (citH4) (113). Compared with pathological ACPAs, tACPAs are extremely rare and extremely inferior in number (115). Therefore, ACPAs in RA patients mainly play pathogenic roles. A new research shows that tACPAs can diminish NET (neutrophil extracellular traps) release and potentially initiate NET uptake by macrophages in vivo, thereby reducing joints damage and disease progression in CIA mice (115). tACPAs opens up new avenues for the therapies for RA, but we still don't know the difference between the B cells that produce pathological ACPA and tACPA, which may be very important for us to understand the role of $B$ cells in RA development. 


\section{THE PROSPECT OF TREATING RA WITH B CELLS AS A TARGET}

\section{Targets B cell Surface Receptors}

The use of Rituximab to deplete B cells is currently the most widely used treatment for treating RA with B cells as a target. CD20 is specifically expressed on the surface of $95 \%$ of human B cells. Rituximab targeting CD20 can deplete all B cells except pro-B cells and plasma cells $(116,117)$. RA patients treated with Rituximab showed positive clinical responses such as decreased synovial B cells, plasma cells, and IgG (118). However, pathogenic B cells and protective $B$ cells treated with rituximab have been eliminated, which will cause a huge immunosuppressive effect in RA patients (Figure 5).

CD38 is mainly expressed on plasmablasts and plasma cells. In vitro experiments show that Daratumumab (an anti-CD38 monoclonal antibody) removes plasma cells and plasmablasts in PBMC of RA patients in a dose-dependent manner (119). Studies have reported that daratumumab has been successful in the treatment of 2 patients with refractory systemic lupus erythematosus, but the efficacy and safety of Daratumumab in the treatment of RA patients still need to be confirmed (120). Abatacept (CTLA-4Ig) has been successfully used to treat autoimmune diseases and has been approved for the treatment of RA. By binding to CD80 and CD86 on the surface of B cells, abatacept inhibits the co-stimulation and activation of T cells, leading to the down-regulation of inflammatory mediators. Studies have shown that Abatacept can inhibit the expression of CD80/CD86 on the surface of B cells in the peripheral blood of RA patients, while reducing the number of plasma cells and the level of serum IgG antibodies (46). In addition, the proportion of B cells in the synovium and ACPA-specific switched memory B-cells in the

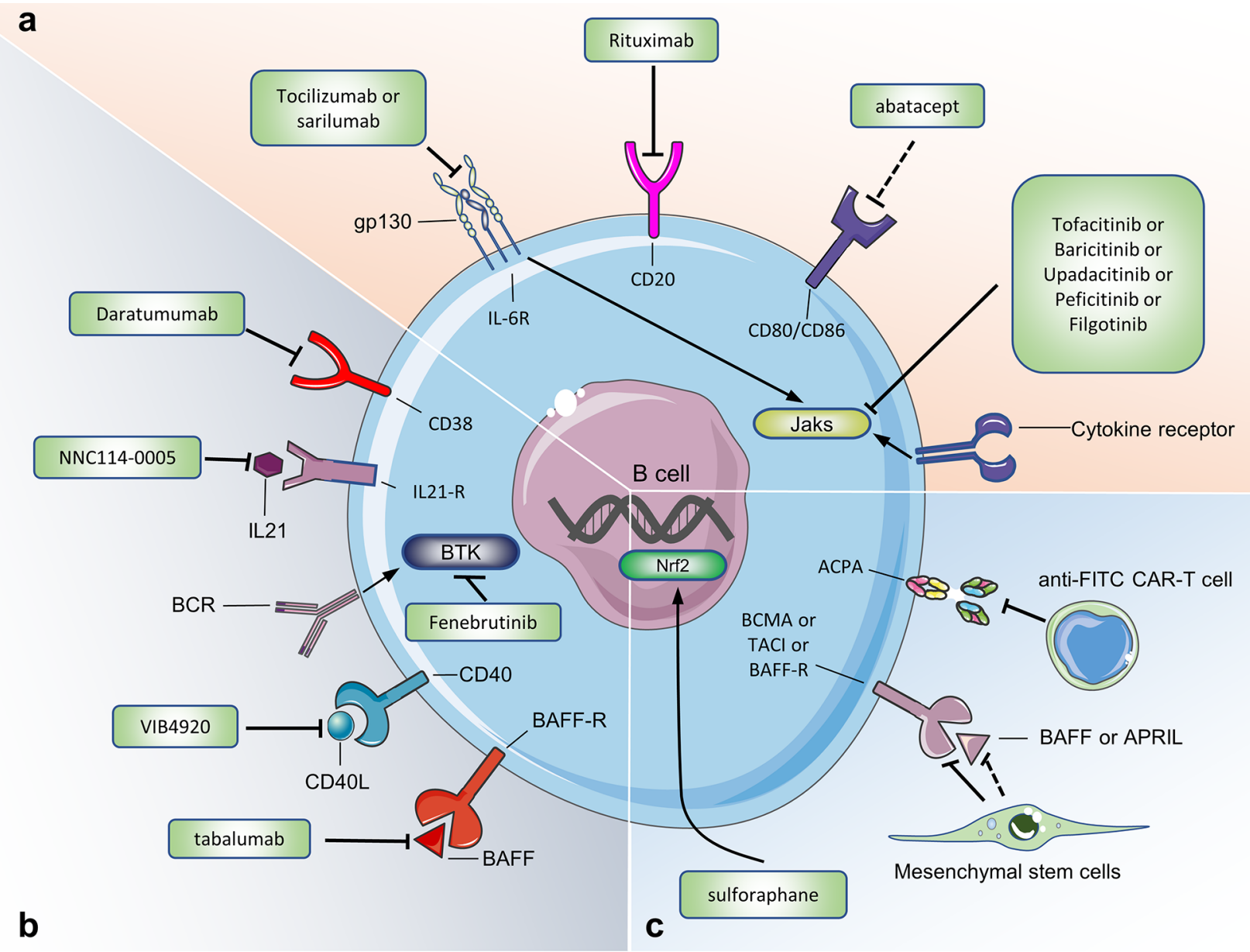

FIGURE 5 | Targeting B cells for current and potential therapeutic approaches in RA. (A) Therapeutic approaches already approved in human. (B) Therapeutic approaches under evaluation in human. (C) Potential therapeutic approaches (only tested in mouse model of CIA or in experiments in vitro). Figure $\mathbf{5}$ summarizes the drugs or cells that target B cells to treat RA. These drugs or cells are either approved in the clinical trial phase of RA, or we believe that they may be used for RA treatment. Jaks, Janus kinases; IL-21R, IL-21 receptor; IL-6R, IL-6 receptor; BAFFR, B cell activating factor receptor; BCMA, B cell maturation antigen; TACl, transmembrane activator and calcium modulator; BTK, Bruton's tyrosine kinase; anti-FITC CAR-T cell, antifluorescein isothiocyanate chimeric antigen receptor $\mathrm{T}$ cells. 
blood serum of RA patients decreased significantly after receiving Abatacept treatment $(46,121)$. ACPA-specific B cells are the main type of autoreactive B cells in RA patients. Co-culture experiments in vitro have shown that anti-FITC CAR-T cells can eliminate FITC-labeled ACPA-specific B cells (122). Whether this clearance effect exists in the body remains to be confirmed, but that study provides a new idea for the future use of CAR-T cell therapy to deplete autoreactive B cells to treat RA.

\section{Targeted B Cell Checkpoints}

Bruton's tyrosine kinase (BTK) is a cytoplasmic tyrosine kinase expressed in B cells, which plays a key role in BCR signal transduction and in the development and maturation of $\mathrm{B}$ cells (123). In the model of arthritis, BTK-deficient mice and BTK inhibitor-treated rodents showed reduced RA progression (124). A randomized, double-blind, phase II clinical trial of the BTK inhibitor Fenebrutinib in the treatment of RA patients $(n=578)$ showed that compared with the placebo group, the Fenebrutinib treatment group $(1 \times 150 \mathrm{mg} /$ day, $2 \times 200 \mathrm{mg} /$ day $)$ has a significant clinical effect (125). Other BTK inhibitors, such as Branebrutinib, are in phase 2 clinical trials for the treatment of RA patients. Nuclear factor E2-related factor 2 (Nrf2) is a transcription factor that plays an important role in cell resistance to oxidative damage. Moon et al. found that sulforaphane can inhibit B cell differentiation and antibody formation to reduce joint inflammation after activating Nrf2 in CIA mice (126).

Mesenchymal stem cells (MSCs) are a type of stem cells that have a wide range of sources, multiple differentiation potentials and immunomodulatory functions. They have been used in multiple clinical trials to treat RA (127). Experiments in vitro show that adipose tissue-derived MSCs co-cultured with peripheral blood $\mathrm{B}$ cells of RA patients can inhibit the proliferation of B cells and reduce the secretion of ACPA (128). Clinical trials have shown that MSCs can reduce joint inflammation by reducing the proportion of $\mathrm{CD} 19^{+} \mathrm{B}$ cells and serum BAFF, APRIL and RF levels in RA patients (129). MSCs mainly act by secreting extracellular vesicles (including exosomes, Exos and microvesicles, MVs). Exos and MVs reduce the potential immune-related risks of MSCs and are a good substitute for MSCs. Cosenza et al. observed that MSC-derived Exos (with a diameter of less than $150 \mathrm{~nm}$ ) can effectively reduce joint inflammation in CIA mice, including reducing the proportion of plasma cells and increasing the proportion of Breg cells in the peripheral blood, while reducing the level of IL-6, IL-1 $\beta$, autoantibodies and increasing the level of IL-10 in the serum (130). Whether Exos derived from MSC has a similar effect on B cells in RA patients remains to be confirmed. In short, MSCs and Exos derived from MSCs have broad application prospects in reducing joint inflammation and repairing the immune function of B cells in RA.

\section{Targeting B Cell Related Cytokines}

The use of TNF inhibitors can significantly reduce the level of IgD CD27 B cells, while increasing the level of Breg cells in RA patients $(35,131)$. Belimumab and Tabalumab are two anti-BAFF biological agents. Clinical studies have shown that, compared with the placebo group, Belimumab shows better efficacy in the treatment of RA patients with $\mathrm{RF}^{+}, \mathrm{ACPA}^{+}, \mathrm{DAS} 28>5.1$ (132).
In addition, compared with the placebo group, the number of RA patients treated with $120 \mathrm{mg}$ of Tabalumab was significantly higher when the ACR20 and ACR50 response rates were reached (133). Long-term treatment with Tabalumab can cause a decrease in total B cells, mature naive B cells, and switched memory B cells in RA patients (134). However, the phase III clinical trial of Tabalumab in the treatment of RA was forced to stop because the interim results did not meet the expected efficacy (135). RA patients who received Atacicept (a biological agent that blocks the combination of BAFF/APRIL and TACI) showed a significant reduction in serum anti-RF levels, but in phase II clinical trials, Atacicept did not show significant clinical improvement compared with the placebo group (136).

Targeting IL-6 has shown efficacy in the treatment of various autoimmune diseases. At present, the anti-IL-6R monoclonal antibodies (tocilizumab and sarilumab) have been approved for the treatment of RA and have shown good efficacy (137). Tocilizumab may reduce the serum ACPA titer of RA patients by increasing the ratio of post-switch memory $\mathrm{B}$ cells (IgD-CD27+)/mature naive $\mathrm{B}$ cells $(138,138)$. In a randomized, double-blind clinical trial for RA, NNC114-0005 (anti-IL-21 Monoclonal antibodies) can reduce the disease activity of RA patients and neutralize IL-21 in their bodies (139). Based on the results of that clinical trial, we can further explore the effects of IL-21 as a target in the treatment of RA.

Janus Kinase (JAK) mediates signal transduction through IL-6R and many other transmembrane receptors (cytokine receptors, $G$ protein-coupled receptors, receptor tyrosine kinases). JAK inhibitors can block the effects of pro-inflammatory cytokines on B cells (140), and five JAK inhibitors (tofacitinib, upadacitinib, baricitinib, peficitinib, filgotinib) have been approved for the treatment of RA. Tofacitinib and upadacitinib inhibit B cell proliferation and activation by blocking signal transduction mediated by JAK1 and JAK3 (141-143). The use of tofacitinib significantly reduce the levels of RF in the peripheral blood of RA patient (144). Baricitinib can inhibit the differentiation of B cells into plasmablasts and inhibit the production of IL-6 (145). Similar to tofacitinib, baricitinib reduces the expression of BAFF in RA synovial fibroblasts, thereby locally inhibiting B cell activation in joints (146). Filgotinib directly inhibits human B cell differentiation and IgG production. After RA patients received filgotinib treatment, the representative of $\mathrm{B}$ cell chemotaxis [chemokine (CXC motif) ligand 13, CXCL13], survival and activation (BAFF), differentiation (IL-2, IL-5, IL-7, IL-21) are significantly reduced (147). In short, JAK inhibitors can treat RA by inhibiting B cell activation, proliferation and differentiation, but further studies are still needed to clarify the exact mechanism of action of JAK inhibitors on B cells and other immune cells.

\section{CONCLUSION}

More and more data show that B cells promote the pathogenesis of RA through a variety of mechanisms. As our understanding of B cells in the pathogenesis of RA gradually improves, we must realize that not all B cells in RA patients are pathogenic. On the one hand, we need to continue to study the mechanism by which autoreactive B cells escape the B cell tolerance checkpoints, so as to further 
understand how pathogenic B cells are produced in RA patients. On the other hand, how to distinguish between pathogenic B cells and protective B cells will become an important direction for precise treatment of RA. In the future, it is very likely that therapies against $\mathrm{B}$ cells that produce autoantibodies will be developed to precisely target pathogenic B cells.

\section{AUTHOR CONTRIBUTIONS}

This article is mainly written by FW. JG and JK wrote part of the manuscript and proofread the manuscript. XW, QN, and JL helped us collect literature information and draw pictures. LZ

\section{REFERENCES}

1. Bombardieri M, Lewis M, Pitzalis C. Ectopic Lymphoid Neogenesis in Rheumatic Autoimmune Diseases. Nat Rev Rheumatol (2017) 13:141-54. doi: 10.1038/nrrheum.2016.217

2. Floudas A, Neto N, Marzaioli V, Murray K, Moran B, Monaghan MG, et al. Pathogenic, Glycolytic PD-1+ B Cells Accumulate in the Hypoxic RA Joint. JCI Insight (2020) 5:e139032. doi: 10.1172/jci.insight.139032

3. Timmer TC, Baltus B, Vondenhoff M, Huizinga TW, Tak PP, Verweij CL, et al. Inflammation and Ectopic Lymphoid Structures in Rheumatoid Arthritis Synovial Tissues Dissected by Genomics Technology: Identification of the Interleukin-7 Signaling Pathway in Tissues With Lymphoid Neogenesis. Arthritis Rheum (2007) 56:2492-502. doi: 10.1002/ art. 22748

4. Duddy ME, Alter A, Bar-Or A. Distinct Profiles of Human B Cell Effector Cytokines: A Role in Immune Regulation? J Immunol (2004) 172:3422-7. doi: 10.4049/jimmunol.172.6.3422

5. Baert L, Manfroi B, Casez O, Sturm N, Huard B. The Role of APRIL - A Proliferation Inducing Ligand - In Autoimmune Diseases and Expectations From Its Targeting. J Autoimmun (2018) 95:179-90. doi: 10.1016/ j.jaut.2018.10.016

6. Canete JD, Celis R, Moll C, Izquierdo E, Marsal S, Sanmarti R, et al. Clinical Significance of Synovial Lymphoid Neogenesis and Its Reversal After AntiTumour Necrosis Factor Alpha Therapy in Rheumatoid Arthritis. Ann Rheum Dis (2009) 68:751-6. doi: 10.1136/ard.2008.089284

7. Gause A, Gundlach K, Zdichavsky M, Jacobs G, Koch B, Hopf T, et al. The B Lymphocyte in Rheumatoid Arthritis: Analysis of Rearranged V Kappa Genes From B Cells Infiltrating the Synovial Membrane. Eur J Immunol (1995) 25:2775-82. doi: 10.1002/eji.1830251010

8. Rosengren S, Wei N, Kalunian KC, Zvaifler NJ, Kavanaugh A, Boyle DL. Elevated Autoantibody Content in Rheumatoid Arthritis Synovia With Lymphoid Aggregates and the Effect of Rituximab. Arthritis Res Ther (2008) 10:R105. doi: 10.1186/ar2497

9. Humby F, Bombardieri M, Manzo A, Kelly S, Blades MC, Kirkham B, et al. Ectopic Lymphoid Structures Support Ongoing Production of ClassSwitched Autoantibodies in Rheumatoid Synovium. PloS Med (2009) 6:e1. doi: 10.1371/journal.pmed.0060001

10. Floudas A, Canavan M, McGarry T, Mullan R, Nagpal S, Veale DJ, et al. ACPA Status Correlates With Differential Immune Profile in Patients With Rheumatoid Arthritis. Cells (2021) 10:647. doi: 10.3390/cells10030647

11. Meednu N, Zhang H, Owen T, Sun W, Wang V, Cistrone C, et al. Production of RANKL by Memory B Cells: A Link Between B Cells and Bone Erosion in Rheumatoid Arthritis. Arthritis Rheumatol (2016) 68:80516. doi: 10.1002/art.39489

12. Filipowicz W, Bhattacharyya SN, Sonenberg N. Mechanisms of PostTranscriptional Regulation by microRNAs: Are the Answers in Sight? Nat Rev Genet (2008) 9:102-14. doi: 10.1038/nrg2290

13. Alivernini S, Kurowska-Stolarska M, Tolusso B, Benvenuto R, Elmesmari A, Canestri S, et al. MicroRNA-155 Influences B-Cell Function Through PU.1 in Rheumatoid Arthritis. Nat Commun (2016) 7:12970. doi: 10.1038/ncomms12970 reviewed the manuscript and proposed final revisions. All authors contributed to the article and approved the submitted version.

\section{FUNDING}

This work was supported by the National Natural Science Foundation of China [grant number 81771768] and by the applied basic research project of Shanxi Science and Technology Department [grant number 201901D111416].

14. Thorarinsdottir K, Camponeschi A, Jonsson C, Granhagen OK, Nilsson J Forslind K, et al. CD21(-/Low) B Cells Associate With Joint Damage in Rheumatoid Arthritis Patients. Scand J Immunol (2019) 90:e12792. doi: $10.1111 /$ sji.12792

15. Wardemann H, Nussenzweig MC. B-Cell Self-Tolerance in Humans. Adv Immunol (2007) 95:83-110. doi: 10.1016/S0065-2776(07)95003-8

16. Peters AL, Stunz LL, Bishop GA. CD40 and Autoimmunity: The Dark Side of a Great Activator. Semin Immunol (2009) 21:293-300. doi: 10.1016/ j.smim.2009.05.012

17. Toubi E, Shoenfeld Y. The Role of CD40-CD154 Interactions in Autoimmunity and the Benefit of Disrupting This Pathway. Autoimmunity (2004) 37:457-64. doi: 10.1080/08916930400002386

18. Karnell JL, Albulescu M, Drabic S, Wang L, Moate R, Baca M, et al. A CD40L-Targeting Protein Reduces Autoantibodies and Improves Disease Activity in Patients With Autoimmunity. Sci Transl Med (2019) 11:eaar6584. doi: 10.1126/scitranslmed.aar6584

19. Christensen SR, Shupe J, Nickerson K, Kashgarian M, Flavell RA, Shlomchik MJ. Toll-Like Receptor 7 and TLR9 Dictate Autoantibody Specificity and Have Opposing Inflammatory and Regulatory Roles in a Murine Model of Lupus. Immunity (2006) 25:417-28. doi: 10.1016/j.immuni.2006.07.013

20. Suthers AN, Sarantopoulos S. TLR7/TLR9- and B Cell Receptor-Signaling Crosstalk: Promotion of Potentially Dangerous B Cells. Front Immunol (2017) 8:775. doi: 10.3389/fimmu.2017.00775

21. Zhang Y, Cao R, Ying H, Du J, Chen S, Wang N, et al. Increased Expression of TLR10 in B Cell Subsets Correlates With Disease Activity in Rheumatoid Arthritis. Mediators Inflammation (2018) 2018:9372436. doi: 10.1155/2018/9372436

22. Chen M, Lin X, Liu Y, Li Q, Deng Y, Liu Z, et al. The Function of BAFF on T Helper Cells in Autoimmunity. Cytokine Growth Factor Rev (2014) 25:3015. doi: 10.1016/j.cytogfr.2013.12.011

23. Zhou X, Xia Z, Lan Q, Wang J, Su W, Han YP, et al. BAFF Promotes Th17 Cells and Aggravates Experimental Autoimmune Encephalomyelitis. PloS One (2011) 6:e23629. doi: 10.1371/journal.pone.0023629

24. Thien M, Phan TG, Gardam S, Amesbury M, Basten A, Mackay F, et al. Excess BAFF Rescues Self-Reactive B Cells From Peripheral Deletion and Allows Them to Enter Forbidden Follicular and Marginal Zone Niches. Immunity (2004) 20:785-98. doi: 10.1016/j.immuni.2004.05.010

25. Moura RA, Cascao R, Perpetuo I, Canhao H, Vieira-Sousa E, Mourao AF, et al. Cytokine Pattern in Very Early Rheumatoid Arthritis Favours B-Cell Activation and Survival. Rheumatol (Oxford) (2011) 50:278-82. doi: 10.1093/rheumatology/keq338

26. Zhang LL, Xiao H, Zhang F, Wu YJ, Shu JL, Li Y, et al. BAFF, Involved in B Cell Activation Through the NF-kappaB Pathway, Is Related to Disease Activity and Bone Destruction in Rheumatoid Arthritis. Acta Pharmacol Sin (2021). doi: 10.1038/s41401-020-00582-4

27. Pone EJ, Zhang J, Mai T, White CA, Li G, Sakakura JK, et al. BCR-Signalling Synergizes With TLR-Signalling for Induction of AID and Immunoglobulin Class-Switching Through the Non-Canonical NF-kappaB Pathway. Nat Commun (2012) 3:767. doi: 10.1038/ncomms1769

28. Herlands RA, Christensen SR, Sweet RA, Hershberg U, Shlomchik MJ. T Cell-Independent and Toll-Like Receptor-Dependent Antigen-Driven 
Activation of Autoreactive B Cells. Immunity (2008) 29:249-60. doi: 10.1016/j.immuni.2008.06.009

29. Zhao J, Guo J, Wang L, Zhou W, Zhang Z. The Role of a ProliferationInducing Ligand (APRIL) in the Pathogenesis of Rheumatoid Arthritis. Scand J Rheumatol (2014) 43:462-9. doi: 10.3109/03009742.2014.905630

30. Wu H, Su S, Wu Y, Wu Y, Zhang Z, Chen Q. Nanoparticle-Facilitated Delivery of BAFF-R siRNA for B Cell Intervention and Rheumatoid Arthritis Therapy. Int Immunopharmacol (2020) 88:106933. doi: 10.1016/ j.intimp.2020.106933

31. Arkatkar T, Du SW, Jacobs HM, Dam EM, Hou B, Buckner JH, et al. B CellDerived IL-6 Initiates Spontaneous Germinal Center Formation During Systemic Autoimmunity. J Exp Med (2017) 214:3207-17. doi: 10.1084/jem.20170580

32. Yeo L, Toellner KM, Salmon M, Filer A, Buckley CD, Raza K, et al. Cytokine mRNA Profiling Identifies B Cells as a Major Source of RANKL in Rheumatoid Arthritis. Ann Rheum Dis (2011) 70:2022-8. doi: 10.1136/ard.2011.153312

33. Wu Q, Zhou X, Huang D, Ji Y, Kang F. IL-6 Enhances Osteocyte-Mediated Osteoclastogenesis by Promoting JAK2 and RANKL Activity In Vitro. Cell Physiol Biochem (2017) 41:1360-9. doi: 10.1159/000465455

34. Scott LJ. Tocilizumab: A Review in Rheumatoid Arthritis. Drugs (2017) 77:1865-79. doi: 10.1007/s40265-017-0829-7

35. Moura RA, Quaresma C, Vieira AR, Goncalves MJ, Polido-Pereira J, Romao VC, et al. B-Cell Phenotype and IgD-CD27- Memory B Cells Are Affected by TNF-Inhibitors and Tocilizumab Treatment in Rheumatoid Arthritis. PloS One (2017) 12:e0182927. doi: 10.1371/journal.pone.0182927

36. Niu X, He D, Zhang X, Yue T, Li N, Zhang JZ, et al. IL-21 Regulates Th17 Cells in Rheumatoid Arthritis. Hum Immunol (2010) 71:334-41. doi: 10.1016/j.humimm.2010.01.010

37. Liu R, Wu Q, Su D, Che N, Chen H, Geng L, et al. A Regulatory Effect of IL21 on T Follicular Helper-Like Cell and B Cell in Rheumatoid Arthritis. Arthritis Res Ther (2012) 14:R255. doi: 10.1186/ar3707

38. Konforte D, Simard N, Paige CJ. IL-21: An Executor of B Cell Fate. J Immunol (2009) 182:1781-7. doi: 10.4049/jimmunol.0803009

39. Sakuraba K, Oyamada A, Fujimura K, Spolski R, Iwamoto Y, Leonard WJ, et al. Interleukin-21 Signaling in B Cells, But Not in T Cells, is Indispensable for the Development of Collagen-Induced Arthritis in Mice. Arthritis Res Ther (2016) 18:188. doi: 10.1186/s13075-016-1086-y

40. Young DA, Hegen M, Ma HL, Whitters MJ, Albert LM, Lowe L, et al. Blockade of the Interleukin-21/Interleukin-21 Receptor Pathway Ameliorates Disease in Animal Models of Rheumatoid Arthritis. Arthritis Rheum (2007) 56:1152-63. doi: 10.1002/art.22452

41. Dam EM, Maier AC, Hocking AM, Carlin J, Ng B, Buckner JH. Increased Binding of Specificity Protein 1 to the IL21R Promoter in B Cells Results in Enhanced B Cell Responses in Rheumatoid Arthritis. Front Immunol (2018) 9:1978. doi: 10.3389/fimmu.2018.01978

42. Espeli M, Smith KG, Clatworthy MR. FcgammaRIIB and Autoimmunity. Immunol Rev (2016) 269:194-211. doi: 10.1111/imr.12368

43. Karnell JL, Dimasi N, Karnell FR, Fleming R, Kuta E, Wilson M, et al. CD19 and CD32b Differentially Regulate Human B Cell Responsiveness. J Immunol (2014) 192:1480-90. doi: 10.4049/jimmunol.1301361

44. Kleinau S. The Impact of Fc Receptors on the Development of Autoimmune Diseases. Curr Pharm Des (2003) 9:1861-70. doi: 10.2174/1381612033454414

45. Hu C, Peng S, Zhao L, Li M, Liu M, Xu Y, et al. Yishen-Tongbi Decoction Inhibits Excessive Activation of B Cells by Activating the FcgammaRIIb/Lyn/ SHP-1 Pathway and Attenuates the Inflammatory Response in CIA Rats. BioMed Pharmacother (2021) 134:111166. doi: 10.1016/j.biopha.2020.111166

46. Lorenzetti R, Janowska I, Smulski CR, Frede N, Henneberger N, Walter L, et al. Abatacept Modulates CD80 and CD86 Expression and Memory Formation in Human B-Cells. J Autoimmun (2019) 101:145-52. doi: 10.1016/j.jaut.2019.04.016

47. Espeli M, Bashford-Rogers R, Sowerby JM, Alouche N, Wong L, Denton AE, et al. FcgammaRIIb Differentially Regulates Pre-Immune and Germinal Center B Cell Tolerance in Mouse and Human. Nat Commun (2019) 10:1970. doi: 10.1038/s41467-019-09434-0

48. Sauer AV, Morbach H, Brigida I, Ng YS, Aiuti A, Meffre E. Defective B Cell Tolerance in Adenosine Deaminase Deficiency Is Corrected by Gene Therapy. J Clin Invest (2012) 122:2141-52. doi: 10.1172/JCI61788

49. Allen CD, Cyster JG. Follicular Dendritic Cell Networks of Primary Follicles and Germinal Centers: Phenotype and Function. Semin Immunol (2008) 20:14-25. doi: 10.1016/j.smim.2007.12.001
50. Detanico T, St CJ, Aviszus K, Kirchenbaum G, Guo W, Wysocki LJ. Somatic Mutagenesis in Autoimmunity. Autoimmunity (2013) 46:102-14. doi: 10.3109/08916934.2012.757597

51. Kongpachith S, Lingampalli N, Ju CH, Blum LK, Lu DR, Elliott SE, et al. Affinity Maturation of the Anti-Citrullinated Protein Antibody Paratope Drives Epitope Spreading and Polyreactivity in Rheumatoid Arthritis. Arthritis Rheumatol (2019) 71:507-17. doi: 10.1002/art.40760

52. Malmstrom V, Gronwall C. The Parallel Worlds of ACPA-Positive and RFPositive B Cells. Nat Rev Rheumatol (2018) 14:626-8. doi: 10.1038/s41584018-0094-5

53. Mahendra A, Yang X, Abnouf S, Adolacion J, Park D, Soomro S, et al. Beyond Autoantibodies: Biologic Roles of Human Autoreactive B Cells in Rheumatoid Arthritis Revealed by RNA-Sequencing. Arthritis Rheumatol (2019) 71:529-41. doi: 10.1002/art.40772

54. Germar K, Fehres CM, Scherer HU, van Uden N, Pollastro S, Yeremenko N, et al. Generation and Characterization of Anti-Citrullinated Protein Antibody-Producing B Cell Clones From Rheumatoid Arthritis Patients. Arthritis Rheumatol (2019) 71:340-50. doi: 10.1002/art.40739

55. O'Neill SK, Shlomchik MJ, Glant TT, Cao Y, Doodes PD, Finnegan A. Antigen-Specific B Cells Are Required as APCs and AutoantibodyProducing Cells for Induction of Severe Autoimmune Arthritis. J Immunol (2005) 174:3781-8. doi: 10.4049/jimmunol.174.6.3781

56. Hill JA, Southwood S, Sette A, Jevnikar AM, Bell DA, Cairns E. Cutting Edge: The Conversion of Arginine to Citrulline Allows for a High-Affinity Peptide Interaction With the Rheumatoid Arthritis-Associated HLA-DRB1*0401 MHC Class II Molecule. J Immunol (2003) 171:538-41. doi: 10.4049/ jimmunol.171.2.538

57. Ting YT, Petersen J, Ramarathinam SH, Scally SW, Loh KL, Thomas R, et al. The Interplay Between Citrullination and HLA-DRB1 Polymorphism in Shaping Peptide Binding Hierarchies in Rheumatoid Arthritis. J Biol Chem (2018) 293:3236-51. doi: 10.1074/jbc.RA117.001013

58. Sidney J, Becart S, Zhou M, Duffy K, Lindvall M, Moore EC, et al. Citrullination Only Infrequently Impacts Peptide Binding to HLA Class II MHC. PloS One (2017) 12:e0177140. doi: 10.1371/journal.pone.0177140

59. Auger I, Balandraud N, Massy E, Hemon MF, Peen E, Arnoux F, et al. Peptidylarginine Deiminase Autoimmunity and the Development of AntiCitrullinated Protein Antibody in Rheumatoid Arthritis: The Hapten-Carrier Model. Arthritis Rheumatol (2020) 72:903-11. doi: 10.1002/art.41189

60. Ueno H, Banchereau J, Vinuesa CG. Pathophysiology of T Follicular Helper Cells in Humans and Mice. Nat Immunol (2015) 16:142-52. doi: 10.1038/ ni.3054

61. Lucas C, Perdriger A, Ame P. Definition of B Cell Helper T Cells in Rheumatoid Arthritis and Their Behavior During Treatment. Semin Arthritis Rheum (2020) 50:867-72. doi: 10.1016/j.semarthrit.2020.06.021

62. Shoda H, Nagafuchi Y, Tsuchida Y, Sakurai K, Sumitomo S, Fujio K, et al. Increased Serum Concentrations of IL-1 Beta, IL-21 and Th17 Cells in Overweight Patients With Rheumatoid Arthritis. Arthritis Res Ther (2017) 19:111. doi: 10.1186/s13075-017-1308-y

63. Cao G, Chi S, Wang X, Sun J, Zhang Y. CD4+CXCR5+PD-1+ T Follicular Helper Cells Play a Pivotal Role in the Development of Rheumatoid Arthritis. Med Sci Monit (2019) 25:3032-40. doi: 10.12659/MSM.914868

64. Wang J, Shan Y, Jiang Z, Feng J, Li C, Ma L, et al. High Frequencies of Activated B Cells and T Follicular Helper Cells Are Correlated With Disease Activity in Patients With New-Onset Rheumatoid Arthritis. Clin Exp Immunol (2013) 174:212-20. doi: 10.1111/cei.12162

65. Nakayamada S, Kubo S, Yoshikawa M, Miyazaki Y, Yunoue N, Iwata S, et al. Differential Effects of Biological DMARDs on Peripheral Immune Cell Phenotypes in Patients With Rheumatoid Arthritis. Rheumatol (Oxford) (2018) 57:164-74. doi: 10.1093/rheumatology/kex012

66. Yanaba K, Bouaziz JD, Haas KM, Poe JC, Fujimoto M, Tedder TF. A Regulatory B Cell Subset With a Unique CD1dhiCD5+ Phenotype Controls T Cell-Dependent Inflammatory Responses. Immunity (2008) 28:639-50. doi: 10.1016/j.immuni.2008.03.017

67. Gomez-Puerta JA, Celis R, Hernandez MV, Ruiz-Esquide V, Ramirez J, Haro I, et al. Differences in Synovial Fluid Cytokine Levels But Not in Synovial Tissue Cell Infiltrate Between Anti-Citrullinated Peptide/Protein AntibodyPositive and -Negative Rheumatoid Arthritis Patients. Arthritis Res Ther (2013) 15:R182. doi: 10.1186/ar4372 
68. Banko Z, Pozsgay J, Szili D, Toth M, Gati T, Nagy G, et al. Induction and Differentiation of IL-10-Producing Regulatory B Cells From Healthy Blood Donors and Rheumatoid Arthritis Patients. J Immunol (2017) 198:1512-20. doi: 10.4049/jimmunol.1600218

69. McInnes IB, Schett G. The Pathogenesis of Rheumatoid Arthritis. N Engl J Med (2011) 365:2205-19. doi: 10.1056/NEJMra1004965

70. Sun W, Meednu N, Rosenberg A, Rangel-Moreno J, Wang V, Glanzman J, et al. B Cells Inhibit Bone Formation in Rheumatoid Arthritis by Suppressing Osteoblast Differentiation. Nat Commun (2018) 9:5127. doi: 10.1038/s41467-018-07626-8

71. Dienz O, Rincon M. The Effects of IL-6 on CD4 T Cell Responses. Clin Immunol (2009) 130:27-33. doi: 10.1016/j.clim.2008.08.018

72. Yeo L, Lom H, Juarez M, Snow M, Buckley CD, Filer A, et al. Expression of FcRL4 Defines a Pro-Inflammatory, RANKL-Producing B Cell Subset in Rheumatoid Arthritis. Ann Rheum Dis (2015) 74:928-35. doi: 10.1136/ annrheumdis-2013-204116

73. Amara K, Clay E, Yeo L, Ramskold D, Spengler J, Sippl N, et al. B Cells Expressing the IgA Receptor FcRL4 Participate in the Autoimmune Response in Patients With Rheumatoid Arthritis. J Autoimmun (2017) 81:34-43. doi: 10.1016/j.jaut.2017.03.004

74. Olalekan SA, Cao Y, Hamel KM, Finnegan A. B Cells Expressing IFN-Gamma Suppress Treg-Cell Differentiation and Promote Autoimmune Experimental Arthritis. Eur J Immunol (2015) 45:988-98. doi: 10.1002/eji.201445036

75. Lee SK, Silva DG, Martin JL, Pratama A, Hu X, Chang PP, et al. InterferonGamma Excess Leads to Pathogenic Accumulation of Follicular Helper T Cells and Germinal Centers. Immunity (2012) 37:880-92. doi: 10.1016/ j.immuni.2012.10.010

76. Kristyanto H, Blomberg NJ, Slot LM, van der Voort E, Kerkman PF, Bakker A, et al. Persistently Activated, Proliferative Memory Autoreactive B Cells Promote Inflammation in Rheumatoid Arthritis. Sci Transl Med (2020) 12: eaaz5327. doi: 10.1126/scitranslmed.aaz5327

77. Kalampokis I, Yoshizaki A, Tedder TF. IL-10-Producing Regulatory B Cells (B10 Cells) in Autoimmune Disease. Arthritis Res Ther (2013) 15(Suppl 1): S1. doi: 10.1186/ar3907

78. Ma L, Liu B, Jiang Z, Jiang Y. Reduced Numbers of Regulatory B Cells Are Negatively Correlated With Disease Activity in Patients With New-Onset Rheumatoid Arthritis. Clin Rheumatol (2014) 33:187-95. doi: 10.1007/ s10067-013-2359-3

79. Adachi Y, Onodera T, Yamada Y, Daio R, Tsuiji M, Inoue T, et al. Distinct Germinal Center Selection at Local Sites Shapes Memory B Cell Response to Viral Escape. J Exp Med (2015) 212:1709-23. doi: 10.1084/jem.20142284

80. Iwata Y, Matsushita T, Horikawa M, Dilillo DJ, Yanaba K, Venturi GM, et al. Characterization of a Rare IL-10-Competent B-Cell Subset in Humans That Parallels Mouse Regulatory B10 Cells. Blood (2011) 117:530-41. doi: 10.1182/blood-2010-07-294249

81. Fortea-Gordo P, Villalba A, Nuno L, Santos-Bornez MJ, Peiteado D, Monjo I, et al. Circulating CD19+CD24hiCD38hi Regulatory B Cells as Biomarkers of Response to Methotrexate in Early Rheumatoid Arthritis. Rheumatol (Oxford) (2020) 59:3081-91. doi: 10.1093/rheumatology/keaa186

82. Flores-Borja F, Bosma A, Ng D, Reddy V, Ehrenstein MR, Isenberg DA, et al. CD19+CD24hiCD38hi B Cells Maintain Regulatory T Cells While Limiting TH1 and TH17 Differentiation. Sci Transl Med (2013) 5:173ra23. doi: 10.1126/scitranslmed.3005407

83. Lee KM, Stott RT, Zhao G, SooHoo J, Xiong W, Lian MM, et al. TGF-BetaProducing Regulatory B Cells Induce Regulatory T Cells and Promote Transplantation Tolerance. Eur J Immunol (2014) 44:1728-36. doi: 10.1002/eji.201344062

84. Shen P, Roch T, Lampropoulou V, O'Connor RA, Stervbo U, Hilgenberg E, et al. IL-35-Producing B Cells Are Critical Regulators of Immunity During Autoimmune and Infectious Diseases. Nature (2014) 507:366-70. doi: 10.1038 /nature 12979

85. Egwuagu CE, Yu CR. Interleukin 35-Producing B Cells (I35-Breg): A New Mediator of Regulatory B-Cell Functions in CNS Autoimmune Diseases. Crit Rev Immunol (2015) 35:49-57. doi: 10.1615/CritRevImmunol.2015012558

86. Evans JG, Chavez-Rueda KA, Eddaoudi A, Meyer-Bahlburg A, Rawlings DJ, Ehrenstein MR, et al. Novel Suppressive Function of Transitional 2 B Cells in Experimental Arthritis. J Immunol (2007) 178:7868-78. doi: 10.4049/ jimmunol.178.12.7868
87. Carter NA, Rosser EC, Mauri C. Interleukin-10 Produced by B Cells is Crucial for the Suppression of Th17/Th1 Responses, Induction of $\mathrm{T}$ Regulatory Type 1 Cells and Reduction of Collagen-Induced Arthritis. Arthritis Res Ther (2012) 14:R32. doi: 10.1186/ar3736

88. Dekkers JS, Verheul MK, Stoop JN, Liu B, Ioan-Facsinay A, van Veelen PA, et al. Breach of Autoreactive B Cell Tolerance by Post-Translationally Modified Proteins. Ann Rheum Dis (2017) 76:1449-57. doi: 10.1136/ annrheumdis-2016-210772

89. Lundberg K, Kinloch A, Fisher BA, Wegner N, Wait R, Charles P, et al. Antibodies to Citrullinated Alpha-Enolase Peptide 1 Are Specific for Rheumatoid Arthritis and Cross-React With Bacterial Enolase. Arthritis Rheum (2008) 58:3009-19. doi: 10.1002/art.23936

90. Wegner N, Wait R, Sroka A, Eick S, Nguyen KA, Lundberg K, et al. Peptidylarginine Deiminase From Porphyromonas Gingivalis Citrullinates Human Fibrinogen and Alpha-Enolase: Implications for Autoimmunity in Rheumatoid Arthritis. Arthritis Rheum (2010) 62:2662-72. doi: 10.1002/ art. 27552

91. Rashid T, Jayakumar KS, Binder A, Ellis S, Cunningham P, Ebringer A. Rheumatoid Arthritis Patients Have Elevated Antibodies to Cross-Reactive and Non Cross-Reactive Antigens From Proteus Microbes. Clin Exp Rheumatol (2007) 25:259-67.

92. Konig MF, Abusleme L, Reinholdt J, Palmer RJ, Teles RP, Sampson K, et al. Aggregatibacter Actinomycetemcomitans-Induced Hypercitrullination Links Periodontal Infection to Autoimmunity in Rheumatoid Arthritis. Sci Transl Med (2016) 8:369ra176. doi: 10.1126/scitranslmed.aaj1921

93. Roudier J, Petersen J, Rhodes GH, Luka J, Carson DA. Susceptibility to Rheumatoid Arthritis Maps to a T-Cell Epitope Shared by the HLA-Dw4 DR Beta-1 Chain and the Epstein-Barr Virus Glycoprotein Gp110. Proc Nat Acad Sci U.S.A. (1989) 86:5104-8. doi: 10.1073/pnas.86.13.5104

94. Ronnelid J, Turesson C, Kastbom A. Autoantibodies in Rheumatoid Arthritis - Laboratory and Clinical Perspectives. Front Immunol (2021) 12:685312. doi: 10.3389/fimmu.2021.685312

95. Rantapaa-Dahlqvist S, de Jong BA, Berglin E, Hallmans G, Wadell G, Stenlund H, et al. Antibodies Against Cyclic Citrullinated Peptide and IgA Rheumatoid Factor Predict the Development of Rheumatoid Arthritis. Arthritis Rheum (2003) 48:2741-9. doi: 10.1002/art.11223

96. Lu DR, McDavid AN, Kongpachith S, Lingampalli N, Glanville J, Ju CH, et al. And Innate Immune Pathways Differentially Drive Autoreactive B Cell Responses in Rheumatoid Arthritis. Arthritis Rheumatol (2018) 70:1732-44. doi: 10.1002/art.40578

97. Avouac J, Gossec L, Dougados M. Diagnostic and Predictive Value of AntiCyclic Citrullinated Protein Antibodies in Rheumatoid Arthritis: A Systematic Literature Review. Ann Rheum Dis (2006) 65:845-51. doi: 10.1136/ard.2006.051391

98. El-Gabalawy H. The Preclinical Stages of RA: Lessons From Human Studies and Animal Models. Best Pract Res Clin Rheumatol (2009) 23:49-58. doi: 10.1016/j.berh.2008.11.004

99. Firestein GS, McInnes IB. Immunopathogenesis of Rheumatoid Arthritis. Immunity (2017) 46:183-96. doi: 10.1016/j.immuni.2017.02.006

100. Choi S, Lee KH. Clinical Management of Seronegative and Seropositive Rheumatoid Arthritis: A Comparative Study. PloS One (2018) 13:e0195550. doi: 10.1371/journal.pone

101. Kissel T, Reijm S, Slot LM, Cavallari M, Wortel CM, Vergroesen RD, et al. Antibodies and B Cells Recognising Citrullinated Proteins Display a Broad Cross-Reactivity Towards Other Post-Translational Modifications. Ann Rheum Dis (2020) 79:472-80. doi: 10.1136/annrheumdis-2019-216499

102. Shi J, Knevel R, Suwannalai P, van der Linden MP, Janssen GM, van Veelen PA, et al. Autoantibodies Recognizing Carbamylated Proteins Are Present in Sera of Patients With Rheumatoid Arthritis and Predict Joint Damage. Proc Natl Acad Sci USA (2011) 108:17372-7. doi: 10.1073/pnas.1114465108

103. Laurent L, Anquetil F, Clavel C, Ndongo-Thiam N, Offer G, Miossec P, et al. IgM Rheumatoid Factor Amplifies the Inflammatory Response of Macrophages Induced by the Rheumatoid Arthritis-Specific Immune Complexes Containing Anticitrullinated Protein Antibodies. Ann Rheum Dis (2015) 74:1425-31. doi: 10.1136/annrheumdis-2013-204543

104. Harre U, Lang SC, Pfeifle R, Rombouts Y, Fruhbeisser S, Amara K, et al. Glycosylation of Immunoglobulin G Determines Osteoclast Differentiation and Bone Loss. Nat Commun (2015) 6:6651. doi: 10.1038/ncomms7651 
105. Rombouts Y, Willemze A, van Beers JJ, Shi J, Kerkman PF, van Toorn L, et al. Extensive Glycosylation of ACPA-IgG Variable Domains Modulates Binding to Citrullinated Antigens in Rheumatoid Arthritis. Ann Rheum Dis (2016) 75:578-85. doi: 10.1136/annrheumdis-2014-206598

106. Hafkenscheid L, Bondt A, Scherer HU, Huizinga TW, Wuhrer M, Toes RE, et al. Structural Analysis of Variable Domain Glycosylation of AntiCitrullinated Protein Antibodies in Rheumatoid Arthritis Reveals the Presence of Highly Sialylated Glycans. Mol Cell Proteomics (2017) 16:27887. doi: 10.1074/mcp.M116.062919

107. Sabouri Z, Schofield P, Horikawa K, Spierings E, Kipling D, Randall KL, et al. Redemption of Autoantibodies on Anergic B Cells by Variable-Region Glycosylation and Mutation Away From Self-Reactivity. Proc Natl Acad Sci USA (2014) 111:E2567-75. doi: 10.1073/pnas.1406974111

108. Sehnert B, Mietz J, Rzepka R, Buchholz S, Maul-Pavicic A, Schaffer S, et al. Neuraminidase Inhibitor Zanamivir Ameliorates Collagen-Induced Arthritis. Int J Mol Sci (2021) 22:1428. doi: 10.3390/ijms22031428

109. Vergroesen RD, Slot LM, Hafkenscheid L, Koning MT, van der Voort E, Grooff CA, et al. B-Cell Receptor Sequencing of Anti-Citrullinated Protein Antibody (ACPA) IgG-Expressing B Cells Indicates a Selective Advantage for the Introduction of N-Glycosylation Sites During Somatic Hypermutation. Ann Rheum Dis (2018) 77:956-8. doi: 10.1136/annrheumdis-2017-212052

110. Suwannalai P, van de Stadt LA, Radner H, Steiner G, El-Gabalawy HS, Zijde CM, et al. Avidity Maturation of Anti-Citrullinated Protein Antibodies in Rheumatoid Arthritis. Arthritis Rheum (2012) 64:1323-8. doi: 10.1002/art.33489

111. Shaw PX, Goodyear CS, Chang MK, Witztum JL, Silverman GJ. The Autoreactivity of Anti-Phosphorylcholine Antibodies for AtherosclerosisAssociated Neo-Antigens and Apoptotic Cells. J Immunol (2003) 170:61517. doi: 10.4049/jimmunol.170.12.6151

112. Ajeganova S, de Faire U, Jogestrand T, Frostegard J, Hafstrom I. Carotid Atherosclerosis, Disease Measures, Oxidized Low-Density Lipoproteins, and Atheroprotective Natural Antibodies for Cardiovascular Disease in Early Rheumatoid Arthritis - An Inception Cohort Study. J Rheumatol (2012) 39:1146-54. doi: 10.3899/jrheum.111334

113. Chirivi RGS. Anti-Citrullinated Protein Antibodies as Novel Therapeutic Drugs in Rheumatoid Arthritis. J Clin Cell Immunol (2013) 01. doi: 10.4172/ 2155-9899.S6-006

114. de Faire U, Su J, Hua X, Frostegard A, Halldin M, Hellenius ML, et al. Low Levels of IgM Antibodies to Phosphorylcholine Predict Cardiovascular Disease in 60-Year Old Men: Effects on Uptake of Oxidized LDL in Macrophages as a Potential Mechanism. J Autoimmun (2010) 34:73-9. doi: 10.1016/j.jaut.2009.05.003

115. Chirivi R, van Rosmalen J, van der Linden M, Euler M, Schmets G, Bogatkevich G, et al. Therapeutic ACPA Inhibits NET Formation: A Potential Therapy for Neutrophil-Mediated Inflammatory Diseases. Cell Mol Immunol (2021) 18:1528-44. doi: 10.1038/s41423-020-0381-3

116. Stashenko P, Nadler LM, Hardy R, Schlossman SF. Characterization of a Human B Lymphocyte-Specific Antigen. J Immunol (1980) 125:1678-85.

117. Dorner T, Burmester GR. The Role of B Cells in Rheumatoid Arthritis: Mechanisms and Therapeutic Targets. Curr Opin Rheumatol (2003) 15:24652. doi: 10.1097/00002281-200305000-00011

118. Teng YK, Levarht EW, Toes RE, Huizinga TW, van Laar JM. Residual Inflammation After Rituximab Treatment is Associated With Sustained Synovial Plasma Cell Infiltration and Enhanced B Cell Repopulation. Ann Rheum Dis (2009) 68:1011-6. doi: 10.1136/ard.2008.092791

119. Cole S, Walsh A, Yin X, Wechalekar MD, Smith MD, Proudman SM, et al. Integrative Analysis Reveals CD38 as a Therapeutic Target for Plasma Cell-Rich Pre-Disease and Established Rheumatoid Arthritis and Systemic Lupus Erythematosus. Arthritis Res Ther (2018) 20:85. doi: 10.1186/s13075-018-1578-z

120. Bag-Ozbek A, Hui-Yuen JS. Emerging B-Cell Therapies in Systemic Lupus Erythematosus. Ther Clin Risk Manag (2021) 17:39-54. doi: 10.2147/ TCRM.S252592

121. Buch MH, Boyle DL, Rosengren S, Saleem B, Reece RJ, Rhodes LA, et al. Mode of Action of Abatacept in Rheumatoid Arthritis Patients Having Failed Tumour Necrosis Factor Blockade: A Histological, Gene Expression and Dynamic Magnetic Resonance Imaging Pilot Study. Ann Rheum Dis (2009) 68:1220-7. doi: 10.1136/ard.2008.091876

122. Zhang B, Wang Y, Yuan Y, Sun J, Liu L, Huang D, et al. In Vitro Elimination of Autoreactive B Cells From Rheumatoid Arthritis Patients by Universal
Chimeric Antigen Receptor T Cells. Ann Rheum Dis (2021) 80:176-84. doi: 10.1136/annrheumdis-2020-217844

123. Pal SS, Dammeijer F, Hendriks RW. Role of Bruton's Tyrosine Kinase in B Cells and Malignancies. Mol Cancer (2018) 17:57. doi: 10.1186/s12943-018-0779-z

124. Liang C, Tian D, Ren X, Ding S, Jia M, Xin M, et al. The Development of Bruton's Tyrosine Kinase (BTK) Inhibitors From 2012 to 2017: A MiniReview. Eur J Med Chem (2018) 151:315-26. doi: 10.1016/j.ejmech.2018.03.062

125. Cohen S, Tuckwell K, Katsumoto TR, Zhao R, Galanter J, Lee C, et al. Fenebrutinib Versus Placebo or Adalimumab in Rheumatoid Arthritis: A Randomized, Double-Blind, Phase II Trial (ANDES Study). Arthritis Rheumatol (2020) 72:1435-46. doi: 10.1002/art.41275

126. Moon SJ, Jhun J, Ryu J, Kwon JY, Kim SY, Jung K, et al. The Anti-Arthritis Effect of Sulforaphane, an Activator of Nrf2, is Associated With Inhibition of Both B Cell Differentiation and the Production of Inflammatory Cytokines. PloS One (2021) 16:e0245986. doi: 10.1371/journal.pone.0245986

127. Lopez-Santalla M, Fernandez-Perez R, Garin MI. Mesenchymal Stem/ Stromal Cells for Rheumatoid Arthritis Treatment: An Update on Clinical Applications. Cells (2020) 9:1852. doi: 10.3390/cells9081852

128. Usha SP, Vidyasagar JV, Kona LK, Ponnana M, Chelluri LK. In Vitro Allogeneic Immune Cell Response to Mesenchymal Stromal Cells Derived From Human Adipose in Patients With Rheumatoid Arthritis. Cell Immunol (2017) 314:18-25. doi: 10.1016/j.cellimm.2017.01.008

129. Gowhari SA, Shariati-Sarabi Z, Tavakkol-Afshari J, Ghasemi A, Ghoryani M, Mohammadi M. A Significant Decrease of BAFF, APRIL, and BAFF Receptors Following Mesenchymal Stem Cell Transplantation in Patients With Refractory Rheumatoid Arthritis. Gene (2020) 732:144336. doi: 10.1016/j.gene.2020.144336

130. Cosenza S, Toupet K, Maumus M, Luz-Crawford P, Blanc-Brude O, Jorgensen C, et al. Mesenchymal Stem Cells-Derived Exosomes Are More Immunosuppressive Than Microparticles in Inflammatory Arthritis. Theranostics (2018) 8:1399-410. doi: 10.7150/thno.21072

131. Banko Z, Pozsgay J, Gati T, Rojkovich B, Ujfalussy I, Sarmay G. Regulatory B Cells in Rheumatoid Arthritis: Alterations in Patients Receiving Anti-TNF Therapy. Clin Immunol (2017) 184:63-9. doi: 10.1016/j.clim.2017.05.012

132. Stohl W, Merrill JT, McKay JD, Lisse JR, Zhong ZJ, Freimuth WW, et al. Efficacy and Safety of Belimumab in Patients With Rheumatoid Arthritis: A Phase II, Randomized, Double-Blind, Placebo-Controlled, Dose-Ranging Study. J Rheumatol (2013) 40:579-89. doi: 10.3899/jrheum.120886

133. Genovese MC, Lee E, Satterwhite J, Veenhuizen M, Disch D, Berclaz PY, et al. A Phase 2 Dose-Ranging Study of Subcutaneous Tabalumab for the Treatment of Patients With Active Rheumatoid Arthritis and an Inadequate Response to Methotrexate. Ann Rheum Dis (2013) 72:1453-60. doi: 10.1136/ annrheumdis-2012-202864

134. Greenwald M, Szczepanski L, Kennedy A, Veenhuizen M, Komocsar WJ, Polasek E, et al. A 52-Week, Open-Label Study Evaluating the Safety and Efficacy of Tabalumab, an Anti-B-Cell-Activating Factor Monoclonal Antibody, for Rheumatoid Arthritis. Arthritis Res Ther (2014) 16:415. doi: 10.1186/s13075-014-0415-2

135. Morais SA, Vilas-Boas A, Isenberg DA. B-Cell Survival Factors in Autoimmune Rheumatic Disorders. Ther Adv Musculoskelet Dis (2015) 7:122-51. doi: 10.1177/1759720X15586782

136. van Vollenhoven RF, Kinnman N, Vincent E, Wax S, Bathon J. Atacicept in Patients With Rheumatoid Arthritis and an Inadequate Response to Methotrexate: Results of a Phase II, Randomized, Placebo-Controlled Trial. Arthritis Rheum (2011) 63:1782-92. doi: 10.1002/art.30372

137. Yao X, Huang J, Zhong H, Shen N, Faggioni R, Fung M, et al. Targeting Interleukin-6 in Inflammatory Autoimmune Diseases and Cancers. Pharmacol Ther (2014) 141:125-39. doi: 10.1016/j.pharmthera.2013.09.004

138. Noguchi A, Yasuda S, Hisada R, Kato M, Oku K, Bohgaki T, et al. Anti-Cyclic Citrullinated Peptide Antibody Titers Decrease in Rheumatoid Arthritis Patients Treated With Tocilizumab: A Pilot Study. Mod Rheumatol (2020) 30:276-81. doi: 10.1080/14397595.2019.1583784

139. Ignatenko S, Skrumsager BK, Mouritzen U, Safety PK. And PD of Recombinant Anti-Interleukin-21 Monoclonal Antibody in a First-in-Human Trial. Int J Clin Pharmacol Ther (2016) 54:243-52. doi: 10.5414/CP202474

140. Kubo S, Nakayamada S, Tanaka Y. Baricitinib for the Treatment of Rheumatoid Arthritis. Expert Rev Clin Immunol (2016) 12:911-9. doi: 10.1080/1744666X.2016.1214576 
141. Rizzi M, Lorenzetti R, Fischer K, Staniek J, Janowska I, Troilo A, et al. Impact of Tofacitinib Treatment on Human B-Cells In Vitro and In Vivo. J Autoimmun (2017) 77:55-66. doi: 10.1016/j.jaut.2016.10.005

142. Martina MN, Ramirez BM, Banon-Maneus E, Moya RD, Hierro-Garcia N, Revuelta I, et al. Inhibition of JAK3 and PKC via Immunosuppressive Drugs Tofacitinib and Sotrastaurin Inhibits Proliferation of Human B Lymphocytes In Vitro. Transplant Proc (2016) 48:3046-52. doi: 10.1016/j.transproceed.2016.07.052

143. Parmentier JM, Voss J, Graff C, Schwartz A, Argiriadi M, Friedman M, et al. In Vitro and In Vivo Characterization of the JAK1 Selectivity of Upadacitinib (ABT-494). BMC Rheumatol (2018) 2:23. doi: 10.1186/s41927-018-0031-x

144. Sonomoto K, Yamaoka K, Kubo S, Hirata S, Fukuyo S, Maeshima K, et al. Effects of Tofacitinib on Lymphocytes in Rheumatoid Arthritis: Relation to Efficacy and Infectious Adverse Events. Rheumatol (Oxford) (2014) 53:9148. doi: 10.1093/rheumatology/ket466

145. Kubo S, Nakayamada S, Sakata K, Kitanaga Y, Ma X, Lee S, et al. Janus Kinase Inhibitor Baricitinib Modulates Human Innate and Adaptive Immune System. Front Immunol (2018) 9:1510. doi: 10.3389/fimmu.2018.01510

146. Bonelli M, Dalwigk K, Platzer A, Olmos CI, Hayer S, Niederreiter B, et al. IRF1 is Critical for the TNF-Driven Interferon Response in Rheumatoid Fibroblast-Like Synoviocytes: JAKinibs Suppress the Interferon Response in RA-FLSs. Exp Mol Med (2019) 51:1-11. doi: 10.1038/s12276-019-0267-6
147. Tarrant JM, Galien R, Li W, Goyal L, Pan Y, Hawtin R, et al. Filgotinib, a JAK1 Inhibitor, Modulates Disease-Related Biomarkers in Rheumatoid Arthritis: Results From Two Randomized, Controlled Phase 2b Trials. Rheumatol Ther (2020) 7:173-90. doi: 10.1007/s40744-019-00192-5

Conflict of Interest: The authors declare that the research was conducted in the absence of any commercial or financial relationships that could be construed as a potential conflict of interest.

Publisher's Note: All claims expressed in this article are solely those of the authors and do not necessarily represent those of their affiliated organizations, or those of the publisher, the editors and the reviewers. Any product that may be evaluated in this article, or claim that may be made by its manufacturer, is not guaranteed or endorsed by the publisher.

Copyright (C) $2021 \mathrm{Wu}$, Gao, Kang, Wang, Niu, Liu and Zhang. This is an open-access article distributed under the terms of the Creative Commons Attribution License (CC BY). The use, distribution or reproduction in other forums is permitted, provided the original author(s) and the copyright owner(s) are credited and that the original publication in this journal is cited, in accordance with accepted academic practice. No use, distribution or reproduction is permitted which does not comply with these terms. 